\title{
Skilled Migration and Economic Performances: Evidence from OECD Countries
}

\author{
Gianluca Orefice ${ }^{a}$
}

JEL-Classification: F22, F12

Keywords: international migration, economic performances,factor mobility

\section{Introduction}

The aim of the paper is to investigate the effect of immigrants' inflows on host country's standard of living, by considering the effects on per capita GDP variation. Looking at the simple correlation between immigration flows and per capita GDP in host countries, we notice a strong positive relation between them, but it is not easy to identify the direction of causality. In this paper by using instrumental variable estimation we are able to determine the effects of immigration flows and their human capital content on host country's economic performances in terms of changes in per capita GDP. If a positive effect of skilled immigrants may be found, interesting policy implications on skill selective policies can be drawn.

Growing international labor migration suggests the importance of this topic in international economics: the percentage of foreign-born population over total population residing (legally) in the USA has increased by 3.6\% from 1995 to 2005, and the percentage of foreign-born over USA total population in 2005 was more than $15 \%{ }^{1}$ In Europe the stock of international migrants as a share of population was $8.8 \%$ in 2005 and it is expected to become $9.5 \%$ in 2010 . Thus migration has, potentially, a crucial role for the comprehension of future economic development: does immigration affect per capita GDP in the host

a I would like to thank G. Barba Navaretti, F. Docquier, T. Frattini, G. Peri, W. Pariente and V. Verardi for helpful comments and suggestions. I also thank participants at the Second Italian Doctoral Workshop in Economics and Policy Analysis (Turin 2-3 July 2009) and participants at the SSES annual meeting, Univeristy of Fribourg 24-25 June 2010. All errors are mine. Gianluca Orefice, department of Economics, Business and Statistics, University of Milan, via Conservatorio 7, 20122 Milano. E-mail: gianluca.orefice@unimi.it.

1 United Nations, Department of Social affairs "Trend in total migrants stock: the 2005 revision" http://esa.un.org/migration. 
countries? Do tertiary educated immigrants affect positively per capita GDP in host countries? These are the main questions that the paper intends to investigate. The debate on the effects of immigration on developed countries is wide and it concerns a lot of social disciplines, among them economics has the role to investigate the economic related effects of immigration. There is a flourishing literature on the effects of both international flows of capital and trade on income growth (Michaely, 1977; Borensztein, De Gregorio and Lee, 1998; Frankel and Romer, 1999; De Mello, 1999; Zhang, 2001), but although migration can be similarly considered as an international factor movement, the link between migration and income variation has been scarcely analysed in literature. Up to now economists focused a lot, both theoretically and empirically, on the labor markets effects of immigration (CARD, 2001 and 2005; BorJas, 2003; Aydemir and Borjas, 2007; Ottaviano and Peri, 2008), because the effects of immigration have been considered passing through the labor market, but it is just one outcome of interest (HANSON, 2008). This is certainly true but also restrictive: immigration, by increasing the labor force, will reduce capital labor ratio in the host country, increasing return on capital and so generating investment opportunities and physical capital accumulation (up to the point in which the marginal product of capital returns to its pre-immigration shock value). Moreover immigrants may affect total factor productivity in host countries, since they may promote specialization/complementarities (OtTAVIANO and Peri, 2008) with natives increasing total factor productivity. Immigrants also bring new ideas reinforcing agglomeration economies (SPARber, 2010). On the other hand it is possible that immigration induces the adoption of less productive technologies (unskilled labor intensive). For these reasons, the effect of immigration on host countries income cannot be analysed exclusively through the labor market channel. OrTEGa and PERI (2009) analyse the effects of immigrants on the growth rate of each component of the GDP function (total factor productivity, employment and physical capital used in production) and on the income growth itself. Finally immigration may increase the host countries' human capital endowment (according to their skill level) and so affecting per capita GDP variation (Goria, Dolado and ICHino, 1994). This is the channel we want to analyse by investigating the effects of high skilled immigrants on host countries' changes in per capita GDP.

The importance of understanding the effects of immigrants and their human capital content on host economies concerns both policy implications, by clearing the consequences of skill selective immigration policies on income, and the welfare of natives in receiving countries. The underlying idea is that immigrants not only increase the country's endowment of low wage workers, leading to a decrease in per capita GDP (because of human capital dilution), but they also 
bring some human capital along them allowing for a potential positive effects on per capita GDP by increasing the human capital level in destination countries (Benhabib, 1996; Kemnitz, 2001). This paper provides an econometric estimation of the impact of immigration flows and their human capital content on host countries' economic performances (per capita GDP variation). In providing empirical evidence of the previous questions, in this paper we follow the procedure by Frankel and Romer (1999) (recently adopted by Ortega and PERI, 2009). To build the instrumental variables for international migration we firstly estimate bilateral flows of migration using a gravity-style model, and then we aggregate the fitted values by destination countries. In the second part of the paper we use instrumental variables to investigate the effects of immigrants' flows on income variation. With respect the existing literature in this field, we try to keep the effect of immigration on changes in per capita GDP by stressing the role of the human capital content by immigrants. The rest of the paper is organized as follows. Section 2 provides a review of existing theoretical and empirical literature on the effects of immigration on income in host economy. Section 3 is devoted to our econometric analysis. In particular Section 3.1 presents some stylized facts; Section 3.2 discusses some problems and solutions concerning the empirical strategy; Section 3.3 explains how we built the instrumental variables and how good they are (because this is a crucial point in this literature); while Section 3.4 presents respectively the effects of immigration flows on per capita GDP. Section 4 concludes.

\section{Review of the Literaure}

From a theoretical point of view the effects of immigration on host country's income level and growth has been widely treated. Early models on the effects of labor mobility considered immigration in an extended version of the traditional Solow-Swan model. Using a simple Cobb-Douglas production function where only physical capital and labor (in efficiency unit) contribute to produce output, by assuming immigrants endowed with zero physical capital, immigration is like an increase in the country's unskilled population, so that everything else being constant, immigration leads to a lower per capita income because of the local physical capital dilution.

In the augmented Solow-Swan model framework (Mankiw, Romer and WeIL, 1992), where human capital also contributes to the production process, if immigrants are assumed to bring human capital along them, human capital dilution may be offset. In this case the key to assess the impact of immigration 
on per capita GDP is whether immigrants bring enough human capital to offset its dilution in the host country. If immigrants own a low quantity of human capital, their impact is similar to a simple faster population growth in slowing per capita GDP. If immigrants' human capital is higher than natives', income will be speeded up (Benhabib, 1996; Friedberg and Hunt, 1995). ${ }^{2}$ Dolado, Goria and Ichino (1994) modified the Mankiw, Romer and Weil (1992) model by considering immigration as a source for both working population growth rate and human capital accumulation. ${ }^{3}$ They consider an economy in which output is produced with labor, human and physical capital by using a Cobb-Douglas constant return to scale technology. Immigration has been introduced in the model by modifying the working population growth rate (including the net immigration rate) and by assuming immigrants endowed with some human capital that modifies the human capital accumulation equation. Using this setting authors conclude that immigration has negative effect on output change and growth in host country, while a higher human capital level owned by immigrants has a positive effect on both output change and income growth rate. ${ }^{4}$

So we may conclude from a theoretical perspective that, by modifying traditional growth model and assuming perfect substitutability between native and foreign born immigrants, the effects of immigration depends on the kind of immigrants: if immigrants own a low quantity of human capital they negatively affect output variation; but the higher is their human capital content, the higher is their (positive) contribution on per capita GDP variation.

Although theoretical works have thrown light on the relation between immigration and changes in per capita GDP, only few empirical studies have been conducted and not a clear picture emerges from these. A seminal paper on the effect of immigration on per capita income growth was by BARRO and SALA-IMARTIN (1992), they find that immigration has no effect on income growth. Dolado, Goria and Ichino (1994), using a panel of 23 OECD countries in the period 1960-1985, found a negative effect of immigration on per capita income growth, concluding that the reason of such negative impact of immigration relies on the fact that immigrants in OECD countries own lower human capital than natives.

2 For more details on the portability of human capital by immigrants, see Friedberg (2000).

3 Notice that in this model immigrants do not contribute to physical capital accumulation.

4 This conclusion holds in the more realistic case in which immigrants own less aggregate human capital than natives. 
Recently empirical papers on the effect of immigration on GDP have been used the so called "accounting approach", which consists of analysing the effect of immigration on every component of per capita output (total factor productivity, physical capital accumulation, employment). The paper by OrTEGa and PERI (2009) adopts this approach and has the merit to find a new way to solve the immigrants' localization endogeneity problem by using the estimated bilateral immigration flows (without wage differential or other economic determinants of migration). Thus they use 2SLS estimates to analyse the effects of immigration on every component of the per capita GDP function. In particular they show that an increasing immigration leads to: (i) an increasing employment growth (confirming one of the main assumption of the growth model by Dolado, Goria and ICHINO, 1994) and (ii) an increasing physical capital growth. They also estimate the effect of immigration on per capita GDP growth finding that a $1 \%$ increase in immigrants flows entails about a $1 \%$ increase in per capita GDP growth rate. Ortega (2008) by estimating the effect of immigration on per capita GDP and labor productivity (per hour worked GDP) finds that a $10 \%$ increase in immigration induced population growth leads to a $3.8 \%$ increase in GDP but to a $6.2 \%$ and $6.7 \%$ reductions in GDP per capita and per hour worked GDP. FELBERMAYR, Hiller and Sala (2010) investigate the effect of immigrants (by using the stock of immigrants in destination country) on per capita GDP in the host countries. Using a IV cross-section approach and controlling for institutional quality, trade and financial openness they find positive correlation between immigration and per capita GDP: a $1 \%$ increase in the migrants stock leads to a $0.22 \%$ increase in per capita GDP. Similarly Bellini, Ottaviano, Pinelli and Prarolo (2009) find that the share of foreigners in total population has a positive effect of per capita GDP in EU destination regions.

Sparber (2010) uses data on 48 US states from 1980-200 to explore the relationship between diversity (that can be seen as a measure of immigrants employment $)^{5}$ and per capita GDP variation. Instrumental variable estimation shows a positive and significant effect of diversity on per capita GDP, but using state fixed effects to account for time invariant income explanatory variable (other that diversity) coefficient becomes insignificant.

5 Index of diversity (racial fractionalization) has been computed as:

$$
R F_{s, t}=1-\sum_{r} \text { employment_share } e_{r, s, t}^{2},
$$

where $s$ is the state, $t$ is time and $r$ is the race of employees (Asia, Blacks, Hispanic, Whites, Others). 
The former empirical investigations on the effects of immigrants on per capita GDP do not take into account an important feature arising from theoretical growth papers: the human capital content of immigrants. It seems that, although theoretical models suggest the importance of the human capital content of immigrants in determining the effect of immigration on per capita GDP, empirical papers did not take into account this dimension in estimating the effects of immigrants flows on income. This is the reason why we decided to estimate the effects of immigration flows on per capita GDP variation taking into account the human capital content of immigrants.

\section{Empirical Strategy}

The main finding of theoretical models in literature is that the effect of immigration on income depends on the human capital content of immigrants. So, by increasing the human capital owned by each immigrant, host countries may mitigate the expected negative effect of immigration on per capita GDP. In this paper we approximate the human capital content of immigrants by their skill level. Thus we analyse the effects of immigrants' inflows and their skill level on income in destination countries:

$$
\begin{aligned}
\ln y_{d, t} & =\eta_{d}+\beta_{1} \ln \left(\text { immi_share }_{d, t}\right) \\
& +\beta_{2}\left[\ln \left(\text { immi_share }_{d, t}\right) * \ln \left(\text { immi_skill }_{d}\right)\right]+\varepsilon_{d, t},
\end{aligned}
$$

where $y_{d, t}$ is per capita GDP in destination country $d$ and at time $t$, immi_share is the share of immigrants inflows over total population and immi_skill is a measure of the human capital content of immigrants inflows.

The fixed effects $\eta_{d}$ controls for unobserved structural differences between countries that are time invariant (for example the initial level of technology, resource endowments, climate institutions). The human capital content of immigrants has been approximated in two ways: (i) as the share between tertiary educated over total immigrants stock; (ii) as the share between tertiary over primary

6 The variable (immi_skill $)$ could not be put in the estimated equation because it is time invariant and it is perfectly correlated with the fixed effects $\eta_{d}$. Since the effect of the skill proportion of immigrants is kept by $\eta_{d}$ we do not incur an omitted variable problem. Moreover, we tried to estimate a LSDV model (that produces the same coefficient as a within estimation) in order to be allowed to insert the $\ln \left(\right.$ immi_skill $\left._{d}\right)$ variable, but the associated coefficient was not statistically different from zero. 
educated immigrants stock (the so called "selection ratio"). Since we used a fixed effects panel data model (within estimator) ${ }^{7}$ to estimate equation (1), by looking at the $\beta_{1}$ coefficient we are able to assess the effect of an increase in the immigrants inflows (with respect to its time mean) on the variation of per capita GDP about its time mean, conditioned to a zero skill content of immigrants. By looking at the $\beta_{2}$ coefficient we also know how being skilled among immigrants changes the effect on per capita GDP variation.

This kind of empirical works are not common in literature, exceptions are Dolado, Goria and Ichino (1994), Felbermayr, Hiller and Sala (2010), Ortega and Peri (2009) and Bellini et.al. (2009), because of a series of econometric problems such as endogeneity from migrants localization, internal migration $^{8}$ and data availability. To this end the empirical strategy consists of two main parts, in the first (Section 3.3) we build the instrumental variables using the Frankel and Romer (1999) approach also used by Ortega and Peri (2009) to solve the endogeneity problem. In the second part we estimate equation (1) by using a 2SLS panel data model (Section 3.4).

\subsection{Data and Descriptive Evidence}

In this paper we combine an international panel data set on bilateral flows of migration from 86 poor and developing countries to 24 OECD countries with some macroeconomic and geographical variables concerning both origin and destination countries. Data on migration come from the International Migration Statistics (IMS) data set from OECD.stat ${ }^{10}$. Notice that this kind of data does not cover illegal migration. In this paper we use flows of migration from 1998 to

7 We could not estimate a simple first difference panel data model, because the lagged dependent variable would be endogenous implying to insert an instrument for it among the other instrumental variables. This does not allow us to solve for the immigrants localization endogeneity.

8 The problem of internal migration does not affect our analysis because it will be conduct at country level. Internal migration introduces a negative bias in sub-national level estimations (HANSON, 2008).

9 Low quality data problem can be solved by providing some reasons for caution in using the foreign born by total residents: (i) a considerable number of foreign born workers in manufacturing industries are skilled (and the education level is hardly comparable between host and origin country); (ii) not all native born workers are skilled and (iii) not all immigrants participate in the labor market, particularly following an intense process of family regrouping in recent years (Friedberg and Hunt, 1995).

10 Here immigrants are defined as the number of foreign born individuals entering in the country with a residence permit at least for one year. So our measure is unaffected by national naturalization policies. 
2007. ${ }^{11}$ Macroeconomic variables such as per capita GDP ${ }^{12}$, per hour worked GDP, population, number of patents, public and private expenditure in tertiary education $^{13}$ and bilateral aid have been taken from OECD.stat as well. From CEPII we take geographic variables such as the distance between countries, dummy variable for common language, past colonial relationship and contiguity of countries. Finally from Docquier, Lowell and Marfouk (2007) database we take data concerning the skill level of immigrants. This dataset contains the stock in 2000 and 1991 of immigrants and native workforce by education level and origin country. Before going to the econometric estimation we want to point out some descriptive evidence on the settlement of immigrants and their skill level.

Table 1 shows the share of tertiary educated over total immigrants stock and the share of immigrants over total population in 2000 for each destination country; as one may expect the main immigrants endowed countries are Luxembourg, Australia and Switzerland; while Italy, Hungary, Portugal and Finland are the less endowed. By the point of view of the skill level of immigrants, Australia, Canada, Ireland, New Zealand and United States have the highest share of tertiary educated immigrants, this is certainly the consequence of skilled immigrants oriented policies. ${ }^{14}$ It would be interesting to compare the human capital content of immigrants with those owned by natives, because as concluded by Dolado, Goria and Ichino (1994) immigration has negative effects on both per capita output and growth if the human capital level owned by immigrants is lower than those for natives. Second and third columns in Table 1 show respectively the ratio between tertiary educated over total immigrants and the same ratio for natives; the tertiary educated share for immigrants is higher than those for natives in Australia, Canada, Czech Republic, Ireland, Italy, Japan, Luxembourg, Netherlands, New Zealand, Norway, Poland, Portugal, Slovak Republic, Spain, Switzerland, United Kingdom.

11 Notice that the disaggregated data on migration flows (by origin and destination countries) don't cover the $100 \%$ of total immigrants inflows in each destination countries, for example the total immigration inflow in Italy in 2007 by origin country is the $91 \%$ of the total immigrants inflows of immigrants; so the disaggregated data set contains some zeros for some origin-destination pairs. So some of these observations are truly zero flows, while others correspond probably to small flows.

12 Per capita GDP is provided in USD at constant prices.

13 Expenditure in tertiary education was initially provided in national currency at current price; but we transform them in USD by using exchange rates from UIC dataset and we clear for inflation but dividing for consumer price index.

14 Immigrants selective immigration policies have been carried out in different ways by countries. For example United States adopts the so called H-1B visa to select skilled immigrants, but other systems are the Canadian or Australian "point system". 
Table 1: Share of Immigrants (Stock 2000) over Total Population, Share of Tertiary Educated over Total Stock of Immigrants in 2000, Share of Tertiary Educated Natives Workers over Total

\begin{tabular}{|c|c|c|c|}
\hline Country & $\begin{array}{c}\text { Share of } \\
\text { immigrants over } \\
\text { total population }\end{array}$ & $\begin{array}{l}\text { Share of tertiary } \\
\text { educated } \\
\text { immigrants }\end{array}$ & $\begin{array}{c}\text { Share of tertiary } \\
\text { educated } \\
\text { native workers }\end{array}$ \\
\hline Australia & 21.2 & 40.3 & 30.9 \\
\hline Austria & 10.2 & 12.7 & 14.6 \\
\hline Belgium & 8.9 & 19.8 & 28.5 \\
\hline Canada & 15.1 & 58.8 & 49.6 \\
\hline Czech Republic & 4.0 & 11.5 & 10.7 \\
\hline Denmark & 4.3 & 17.3 & 21.8 \\
\hline Finland & 1.7 & 23.8 & 26.3 \\
\hline France & 6.1 & 16.4 & 22.4 \\
\hline Germany & 5.7 & 21.8 & 25.8 \\
\hline Hungary & 1.1 & 11.6 & 12.0 \\
\hline Ireland & 7.4 & 41.1 & 16.3 \\
\hline Italy & 1.6 & 15.4 & 8.5 \\
\hline Japan & 0.8 & 28.1 & 23.8 \\
\hline Luxembourg & 22.9 & 21.7 & 30.3 \\
\hline Netherlands & 11.3 & 22.0 & 21.9 \\
\hline New Zealand & 13.8 & 40.9 & 21.6 \\
\hline Norway & 5.0 & 28.7 & 21.2 \\
\hline Poland & 1.9 & 14.0 & 11.0 \\
\hline Portugal & 1.4 & 18.6 & 8.6 \\
\hline Slovak Republic & 0.7 & 15.2 & 11.5 \\
\hline Spain & 3.9 & 18.5 & 11.8 \\
\hline Sweden & 8.6 & 25.7 & 27.7 \\
\hline Switzerland & 20.9 & 18.6 & 16.6 \\
\hline United Kingdom & 6.0 & 34.9 & 16.1 \\
\hline United States & 8.6 & 42.7 & 52.5 \\
\hline
\end{tabular}

Source: author on F.Docquier, A.Marfouk and B.L.Lowell (2007). 
A second feature arising from the data is the decreasing persistency of immigrants' inflows localization along time (Figure 1). One may notice that the stock of immigrants in 1991 is well correlated (slope statistically different from zero) with the inflows of immigrants over total population in 1998, but not well correlated with the inflows of immigrants over total population in 2007. Figure 2 shows the positive and statistically significant correlation between the share of tertiary educated over total immigrants in 2000 and the stock of tertiary educated over total native workforce. It is interesting to notice that United States and Canada have the highest shares of tertiary educated immigrants and natives; on the contrary Portugal and Italy have the lowest share of tertiary educated immigrants and natives. Figure 2 also shows the relation between the share of tertiary educated over total immigrants in 2000 and the share of immigrants over total resident population, it seems that tertiary educated immigrants go in average where all other immigrants localize.

\subsection{The Empirical Approach: Problems and Solutions}

One main problem arises in empirical estimation when migration is involved as independent variable: endogeneity from immigrants' localization choice. Endogeneity arises if immigrants choose where to stay on the basis of country's wage or GDP differentials within origin and destination countries. Thus it is true not only that immigration drives economic performances (or labor market changes), but also that local economic performances drive immigration. This problem leads to a biased estimation of the effects of immigration on economic performances. The endogeneity problem can be solved by using instrumental variables: if one can find a variable correlated with the change in immigrants' presence but independent by the local economic performance, the bias due to immigration choice can be removed. When immigrants choose the country where to stay, they can take into account also other aspects of a region, such as existing networks and the presence of a community with the same culture and language. Thus, besides economic performance reasons, immigrants may tend to settle in countries (or cities) with high density of immigrants. Since the stock of existing immigrants in a region is unlikely to be correlated with current economic shocks (notice that a sufficient time lag is necessary), historic settlement pattern may solve the endogeneity problem. Figure 3 shows not statistically significant, even if positive, correlation between the stock of immigrants in 1991 and the per capita GDP in 1998 and 2007..$^{15}$ Altonji and CARD (2001) used the stock of immigrants in 1970 as

15 We chosen 1998 and 2007 as starting and ending years of our panel. 


\section{Figure 1: Relation between the Inflows of Migrants and the Stock of Immigrants in 1991}

(a)

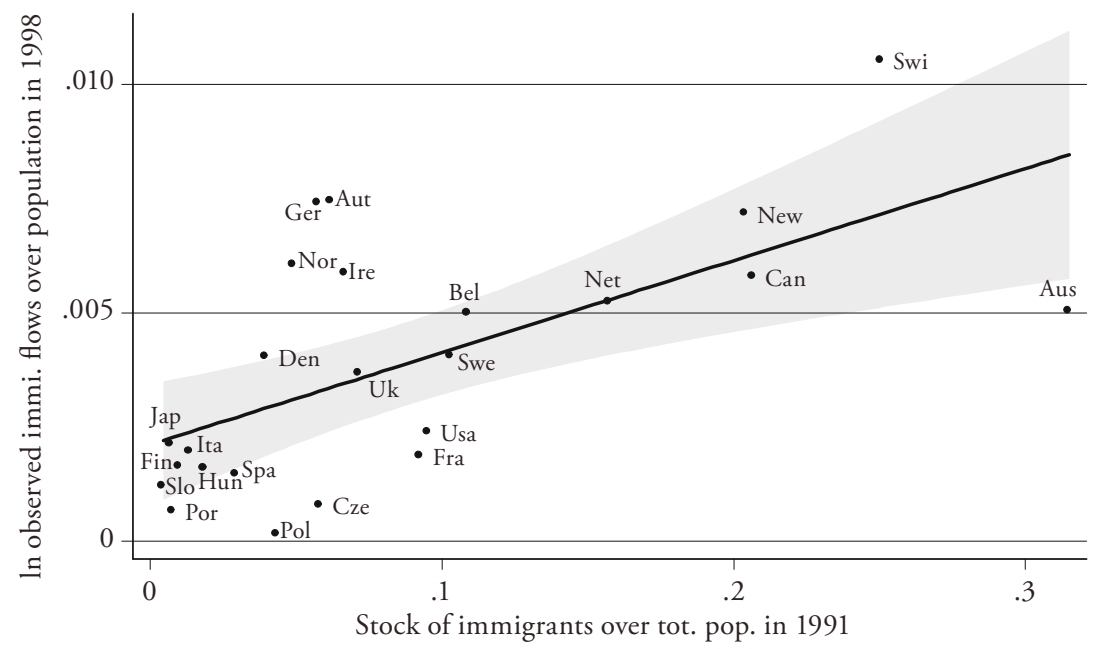

(b)

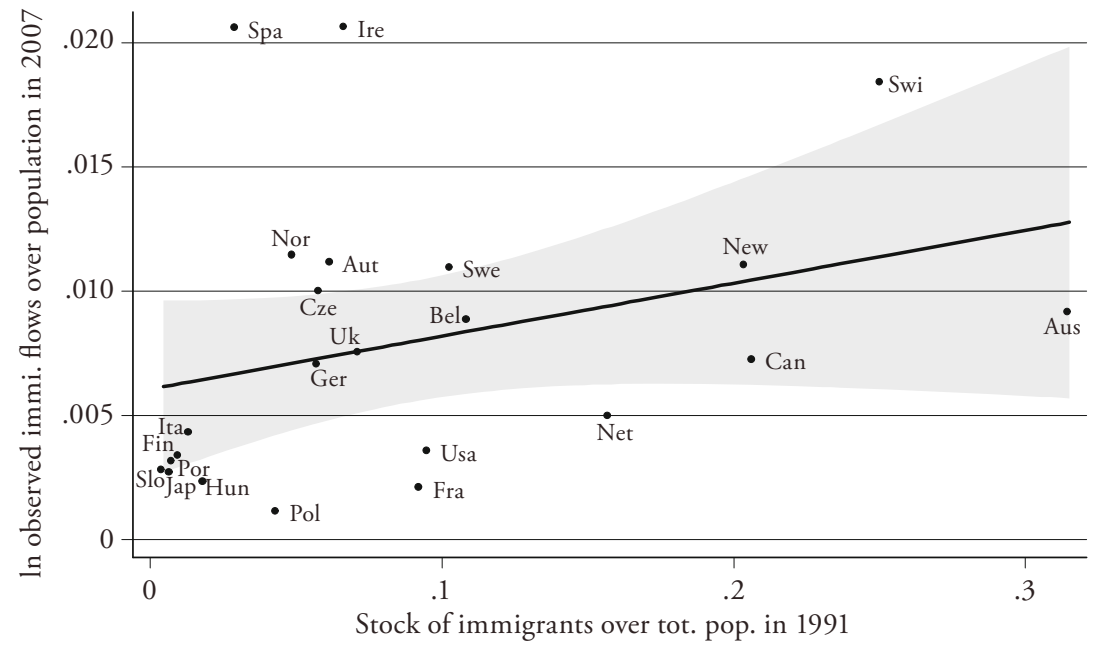

95\% CI - Fitted values - immi_share

Source: F. Docquier, A. Marfouk and B.L.Lowell; and OECD.stat. 
Figure 2: Relation between the Share of Skilled Immigrants in 2000 and:

(a) the Share of Skilled Native Workers in 2000,

(b) the Share of Immigrants over Total Population in 2000

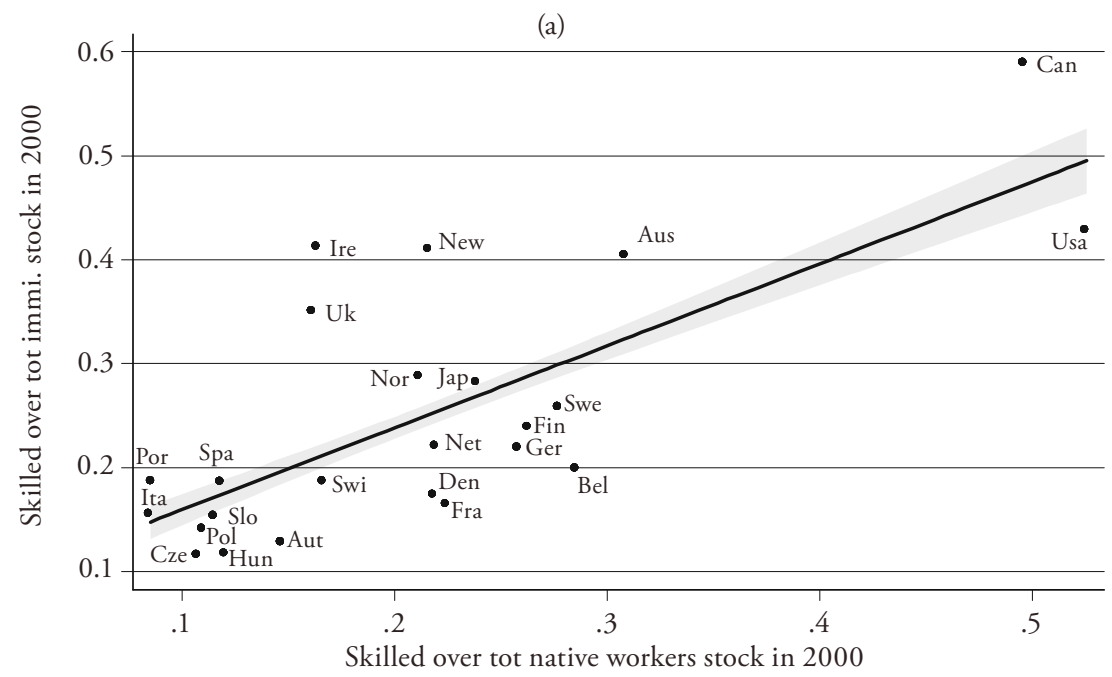

(b)

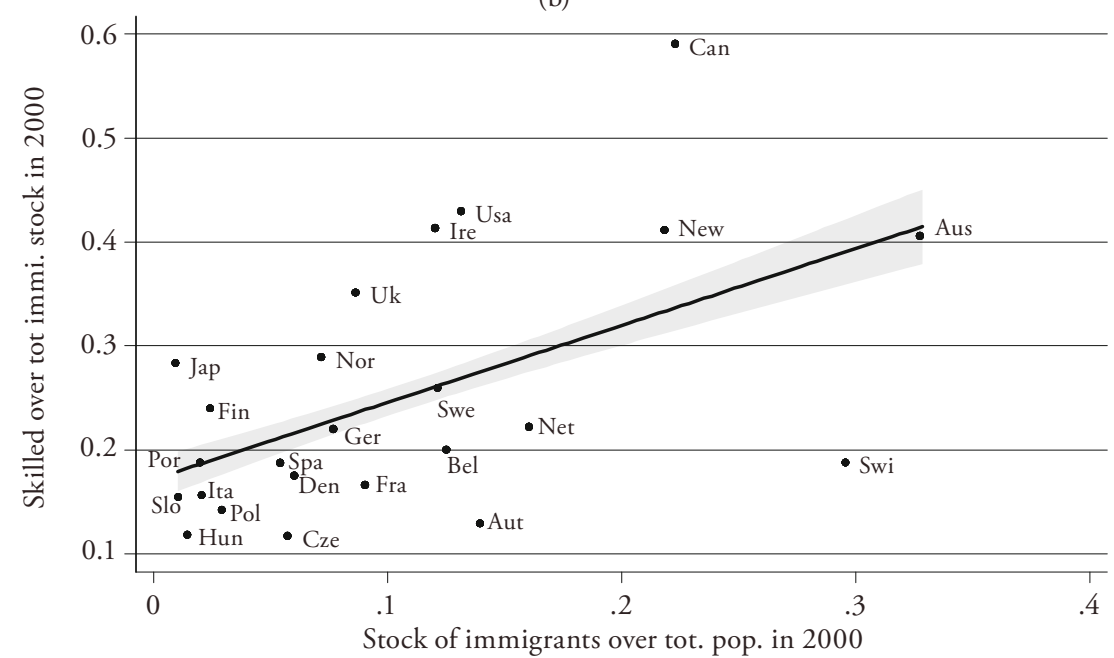

95\% CI - Fitted values - tertiary_edu_share_2000

Source: F. Docquier, A. Marfouk and B.L.Lowell; and OECD.stat. 
an instrumental variable for the change in immigrant population between 1970 and 1980 in USA cities. The logic is the following: new immigrants tend to go where other immigrants already reside, but this variable is uncorrelated with local economic outcomes or wages. An alternative way to overcome the endogeneity problem was recently proposed by MAYDA (2008) and used by OrTEgA and PERI (2009). They estimated the gravity-push bilateral immigration flows without economic determinants, and thus the fit of this regression was used as an instrumental variable (by aggregating data for each destination country). In this way the instrumental variable results to be well correlated with immigration flows and mainly independent from economic shocks. ${ }^{16}$ In this paper we follow the former approach. ${ }^{17}$ Hence, our empirical approach consists of two steps; firstly we'll estimate the bilateral flows of immigrants (both total and skilled ones) by using geographic and strictly exogenous determinants of migration, ${ }^{18}$ and we'll aggregate the flows of immigrants from all origin countries for each destination country (in this way for each destination country we have an estimated immigrants inflows not driven by economic performance as instruments). ${ }^{19}$ The second step is to estimate the effects of immigration on host countries income as in equation (1) by using a 2SLS estimation.

\subsection{Constructing the Instruments}

Our final purpose is to estimate the effect of both immigrants' inflow and its skill content on host country's income variation, thus we have two potentially endogenous variables in our main empirical equations (1). So we need at least two instrumental variables to correctly identify the model and overcome the endogeneity problem. As anticipated in the former section we build these two instruments by estimating bilateral flows of both total and skilled migration using geographic and strictly exogenous determinants. An instrumental variable has

16 This is true under the condition that regressors used to estimate the bilateral immigration flows are independent from any economic shock.

17 We also tried to use the instrument by CARD (2001) using the stock of immigrants in 1990 as a base year for our instrumental variable. But we preferred the approach by OrTEGA and PERI (2009) because it better explains the actual immigration flows than the instrument à la Card (2001).

18 For example we did not use wage differential between origin and destination country that has a strong explanatory power for migrants flows but it would introduce a bias in our estimates.

19 We cannot put the determinants of immigrants flows directly as instrumental variables in the 2SLS procedure because most of them are time invariant and they would be perfectly correlated with the fixed effect in the first stage regression. 
Figure 3: Relation between the Stock of Immigrants in 1991 and per capita GDP in 1998 (a) and 2008 (b)

(a)

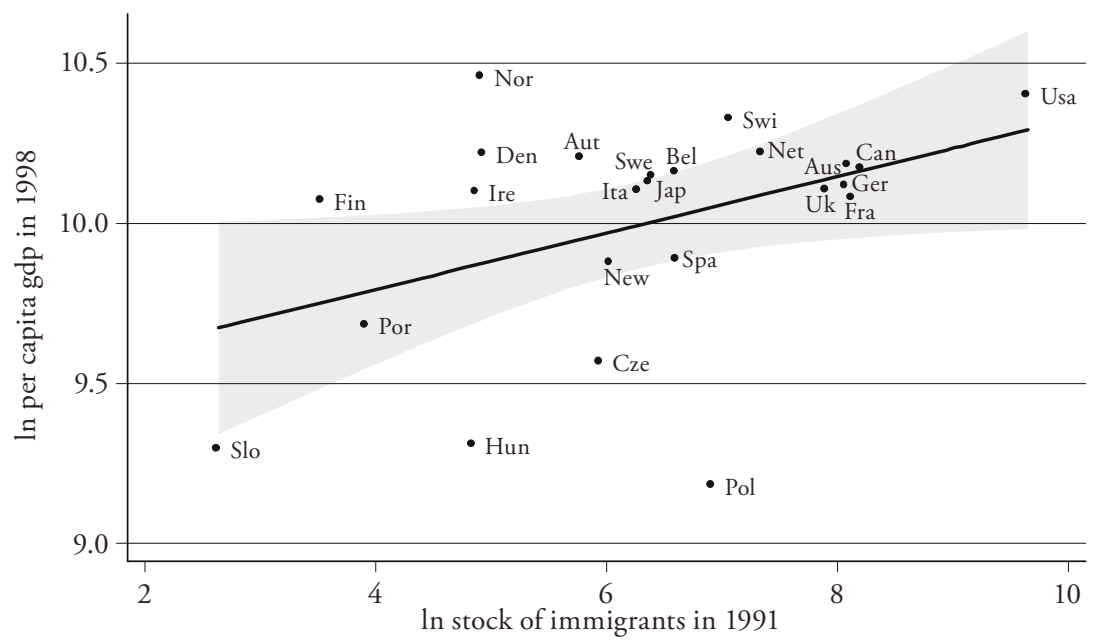

(b)

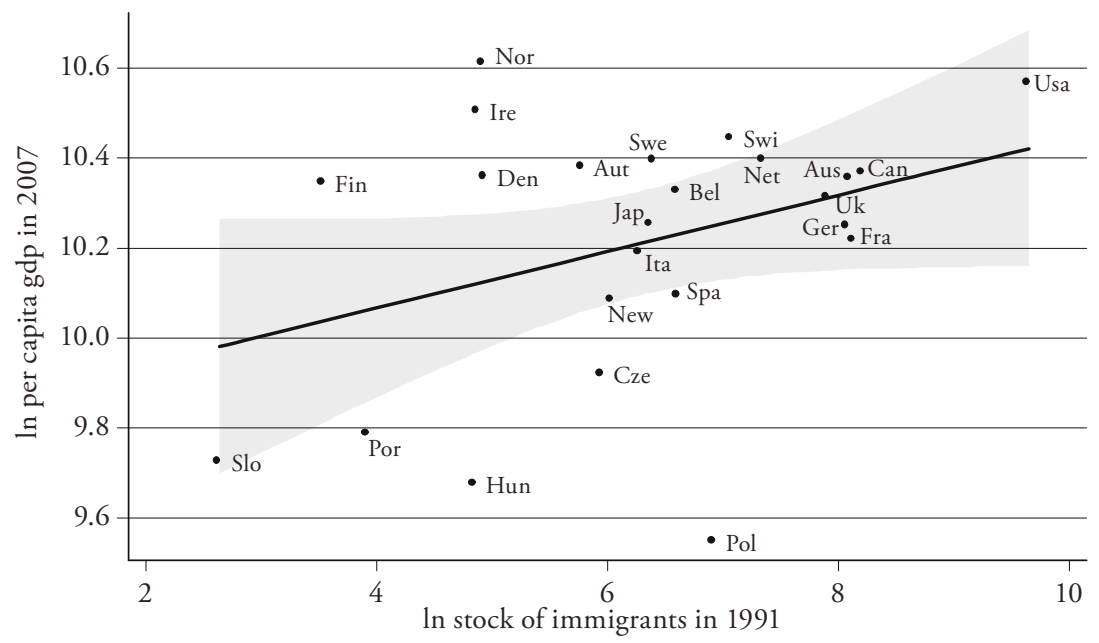

95\% CI - Fitted values $\quad \cdot \ln \_g d p$

Source: F. Docquier, A. Marfouk and B.L.Lowell; and OECD.stat. 
to satisfy two requirements: it must explain quite well the endogenous variable (relevance) and it has to be orthogonal to the error process (validity). In what follows we build the instrumental variables and we will discuss the quality of the instruments providing both qualitative arguments on the exogeneity of variables used to build our instruments and formal test of relevance and validity of the so built instruments.

\subsubsection{The Bilateral Migration Flows Equations}

Our instrumental variables are the estimated immigrants' inflows resulting from the estimation of bilateral migration flows from poor countries to $24 \mathrm{OECD}$ countries (Table 2 reports the countries of origin and destination used in the estimation). Although for the estimation of the empirical equation (1) we just need the inflows of immigrants in every destination country from all over the world, we decided to build instrumental variables by estimating bilateral immigration flows because it enables us to use strictly exogenous variable as migration determinants. ${ }^{20}$ We used data at country level because, as Borjas and Katz (2007), and Ottaviano and Peri (2008) argued, the country is the appropriate unit with which to analyze the effects of migration. The reason is the high degree of mobility of workers and physical capital within country. In our setting we need two instruments, one should look at explaining the total bilateral migration flows from poor to destination countries, and the other looking at the skilled migrants flows (since the interacted variable in the main equation (1) points to measure the effect of being skilled among immigrants). So we estimated the bilateral inflows of immigrants by using two sets of explanatory variables: one set of variables explaining total immigration (both high and low skilled immigrants inflows), the other set explaining high skilled immigrants' inflows. In defining the set of variables explaining the overall bilateral migration flows (equation (2)) we use three main features in literature: (i) migration is positively correlated with bilateral aid (Berthelemy, Beuran and Maurel, 2009); (ii) migration is positively correlated with past immigrants settlements (CARD, 2001; BeIne, Docquier and OzDEN, 2009); (iii) geographic variables are important to estimate bilateral migration flows (Mayda, 2008; Berthelemy, Beuran and Maurel, 2009;

20 In fact geographic variables as distance, past colonial relationship, common language are shown being good migration determinants (Mayda, 2008; Berthelemy, Beuran and Maurel, 2009; Ortega and Peri, 2009) and they could be used only by estimating bilateral immigration flows. 
Table 2: List of the Destination and Origin Countries

\begin{tabular}{l|l}
\hline Destination Countries & Origin Countries \\
\hline Australia, Austria, Belgium, & Albania, Algeria, Argentina, Bangladesh, Belarus, Bolivia, \\
Canada, Czech Republic, & Brazil, Burundi, Cambodia, Cameroon, Canada, Central \\
Denmark, Finland, France, & African Republic, Chad, Chile, China, Colombia, Congo, \\
Germany, Hungary, Ireland, & Costa Rica, Cote d,Ivoire, Croatia, Cuba, Cyprus, \\
Italy, Japan, Netherlands, & Dominican Republic, Ecuador, Egypt, El Salvador, Eritrea, \\
New Zealand, Norway, & Ethiopia, Fiji, Georgia, Ghana, Guatemala, Guinea, \\
Poland, Portugal, Slovak & Guyana, Haiti, Honduras, Hungary, Iceland, India, Iran, \\
Republic, Spain, Sweden, & Iraq, Israel, Jamaica, Kenya, Korea, Lebanon, Liberia, \\
Switzerland, United & Libya, Macedonia, Malaysia, Mali, Mauritania, Mexico, \\
Kingdom, United States & Morocco, Mozambique, Namibia, Nepal, Nicaragua, \\
& Nigeria, Pakistan, Panama, Paraguay, Peru, Philippines, \\
& Rwanda, Saudi Arabia, Senegal, Serbia, Sierra Leone, \\
& Singapore, Slovenia, Somalia, South Africa,Sri Lanka, \\
& Sudan, Suriname, Syria, Thailand, Togo, Tunisia, Ukraine, \\
& Uruguay, Venezuela, Viet Nam, Zambia, Zimbabwe \\
\hline
\end{tabular}

Ortega and Peri, 2009). Thus the overall bilateral flows for immigrants have been estimated by using the following equation:

$$
\begin{aligned}
\ln \left(\text { immi_flows }_{d, o, t}\right) & =\alpha_{o, t}+\gamma_{1} \ln \left(\text { aid }_{d, o, t}\right)+\gamma_{2} \ln \left(\text { immi_stock }_{d, 1991}\right) \\
& +\gamma_{3} \text { distance }_{d, o}+\gamma_{4} \text { language }_{d, o}+\gamma_{5} \text { contiguity }_{d, o} \\
& +\gamma_{6} \text { colony }_{d, o}+\varsigma_{o, d, t}
\end{aligned}
$$

To be sure about the exogeneity of the fitted immigration share from (2) we briefly discuss the exogeneity (and the intuition behind) of each regressor. It is straightforward to consider bilateral aid $\left(\right.$ aid $\left._{d, 0, t}\right)$ as independent from the destination country's economic performance because of bilateral aid is a political exogenous decision by national governments (as an example the overall aid expenditure by United States is lower than the aid expenditure of Portugal, Spain and New Zealand) and also depends on the goodness of political relation with the receiving country; ${ }^{21}$ moreover bilateral aid does not affect directly per capita

21 Moreover the simple correlation index between per capita GDP and overall international aid by each destination countries is 0.196 . 
income in donors countries except for the attractiveness of immigrants. As in Berthelemy, Beuran and Maurel (2009) bilateral aid is expected to have a positive effect on bilateral migration flows through the so called "attraction" effect: more bilateral aid from a "rich country" (destination country in our setting) to a "poor country" (origin country in our case) intensifies the attractiveness of the donor for workers in the "poor countries"; moreover bilateral aid increases the information in poor countries about the donor and it will reduce migration costs. The stock of immigrants in destination country in 1991 (immi_stock ${ }_{d, 1991}$ ) is expected to have a positive effect on bilateral migration because immigrants already living in the destination country reduce the cost of information on how to get a job in the new country, on social system, immigration policy and culture. The stock of immigrants in 1991 may be considered exogenous because of the sufficient time lag with respect per capita income in the main equation (1) (where the dependent variable goes from 1998 to 2007). Moreover, the stock of immigrants in a decade before has been used as instrumental variable in various papers in literature (CARD, 2001; CorTes, 2008). ${ }^{22}$ Evidence of the exogeneity of the stock of immigrants in 1991 with respect economic performance in 1998-2007 is provided in Figure 3, where the correlation between the per capita GDP and the stock of immigrants is positive but not statistically different from zero. Finally, geographic variables concerning destination and origin countries are distance $\left(\right.$ distance $\left._{d, 0}\right),{ }^{23}$ the existence of a common language (language $\left.e_{d, 0}\right)$, the existence of a present or past colonial link $\left(\operatorname{colony}_{d, 0}\right)$ and geographic contiguity $\left(\right.$ contiguity $\left._{d, o}\right)$. All the geographic variables can be easily considered as exogenous. The distance between origin and destination countries may be considered as a proxy for the cost of migration, the further away are the two countries the higher is the cost for migration. Common land border is likely to encourage migration because of lower travel time (and costs). Past or present colonial relationship should increase bilateral flows of migration because of a strong political relation between the two countries.

22 The underlying idea is that unobserved factors determining that more immigrants decided to locate in country "A" rather than in country "B" in 1991 are not correlated with changes in the relative economic performances by the two countries.

23 In our estimation we used the population weighted distance, where the distance in Km between the largest cities in the two countries (origin, destination) is weighted for the share of those cities over the total country's population (see Frankel and ROMER, 1999). This is because the larger is a country the farther is the distance from other countries, so if we do not weight the distance for the population we may end up with migration flows positively affected by distance. 
The second instrumental variable comes from the estimated bilateral skilled immigrants flows as in the following equation (3):

$$
\begin{aligned}
\ln \left(\text { skilled_immi_flows }_{d, o, t}\right) & =\alpha_{o, t}+\theta_{1} \ln \left(\text { edu_exp }_{d, t}\right)+\theta_{2} \ln \left(\text { patent }_{d, t}\right) \\
& +\theta_{3} \ln \left(\text { skilled_immi_stock }_{d, o, 1991}\right) \\
& +\theta_{4} \text { distance }_{d, o}+\theta_{5} \text { Language }_{d, o} \\
& +\theta_{6} \text { contiguity }_{d, o}+\theta_{7} \text { colony }_{d, o}+\varsigma_{o, d, t},
\end{aligned}
$$

where the skilled immigrants bilateral flows have been computed as the product between the bilateral flows of immigrants at time $t$ and the share of tertiary educated immigrants stock in $2000:^{24}$

$$
\begin{aligned}
\text { skilled_immi_flows }_{d, o, t} & =\text { immi_flows }_{d, o, t} \\
& *\left(\frac{\text { skilled_immi_stock }}{\text { d }_{d, o, 2000}}\right) .
\end{aligned}
$$

In order to estimate the skilled immigrants flows we used regressors explaining mainly tertiary educated immigrants flows. Destination countries with both a high expenditure in tertiary education ${ }^{25}\left(e d u_{-} \exp _{d, t}\right)$ and an high number of patents ${ }^{26}$ (patent) should attract in particular tertiary educated immigrants (similar reason for the stock of tertiary educated immigrants in 1991, skilled_immi_stock $\left.{ }_{d, 0,1991}\right)$. These variables may also be considered exogenous with respect per capita GDP because it is difficult to think that expenditure in education and patents could have relevant effects on income in the same year, ${ }^{27}$ except through their impact on the attractiveness of skilled immigrants. Moreover, the expenditure in tertiary level education may be considered exogenous with respect per capita GDP because this kind of expenditure is mainly policy driven (it is not necessarily true that the more is the per capita GDP the more is the expenditure in tertiary level education). The number of patents depends upon the innovation

24 Data on the stock of migrants in 1990 has been used to compute the flows of skilled migrants up to 2001.

25 It is the expenditure of public and private institutions.

26 Number of patent applications to EPO per thousands of inhabitants in the inventor's country of residence.

27 We know that in the long run expenditure in education and innovation activities bring to raise income, but in our estimation they are used at the same year of income. 
activities by firms and institution and scarcely depends on the income in destination countries. Finally, the stock of skilled immigrants in 1991 may considered exogenous because of a sufficient time lag with respect economics performances in main equation (1). After estimating equations (2) and (3) we have the fitted values for bilateral flows of immigration, then we can aggregate these flows for each destination country ending up with the estimated inflows of both total and skilled immigrants in each destination country form 1998 to 2007, and these will be our two instrumental variables.

\subsubsection{Results}

Equation (2) and (3) have been estimated by a fixed effect panel data model, the origin-time fixed effects capture any economic, demographic and cost determinant of migration out of country $o$ which varies over time; these fixed effects capture the so called "push-factors" of immigration which depend only on the conditions in the countries of origin (they are independent of the destination countries' characteristics) such as the per capita GDP, wage level in the origin countries or the share of young over the total population. Since the fixed effect is origin country but also time specific, it will keep also some historical (exogenous) shocks in the immigration flows. For example, the 2004 European Union enlargement probably caused a great increase in the emigration rate from new member countries toward old member countries (especially for those with common borders); this kind of shocks have been taken into account by the origin-time fixed effects. We decided to use origin country-time fixed effects because we want explicitly account for the geographic variables that are origin-destination specific; moreover we could not use destination-time fixed effects because they would keep some destination country's specific economic aspects. The geographic variables are destination-origin country specific and so capture the fixed bilateral cost of migration.

Table 3 shows the results from the estimated equation (2). ${ }^{28}$ All the explanatory variables are strongly significant and, as we expected, bilateral aid positively affects migration flows from origin to destination country, this is coherent with results in Berthelemy, Beuran and Maurel (2009). The stock of immigrants in destination countries in 1991 has a positive effect on migration flows confirming a well known result in literature (CARD, 2001). Geographic variables are significant. As we argued, common language, contiguity and colonial relationship

28 Notice that although we have 24 destination countries, 86 origin countries and 10 years, we estimated equation (3) using just 4945 observations because of a huge number of missing values for bilateral flows of immigrants and international aid in OECD dataset. 
Table 3: Results for Bilateral Migration Flows Estimation: 1998-2007 in 24 OECD Countries from 86 Poor and Developing Countries

Dependent variable

Bilateral immigrants flows in $\ln$

(1)

(2)

(3)

(4)

\begin{tabular}{|c|c|c|c|c|}
\hline ln_aid & $\begin{array}{c}0.37 \\
(33.97)^{* * *}\end{array}$ & $\begin{array}{c}0.289 \\
(25.45)^{* * *}\end{array}$ & $\begin{array}{c}0.216 \\
(19.36)^{* * *}\end{array}$ & $\begin{array}{c}0.288 \\
(17.41)^{* * *}\end{array}$ \\
\hline In_immi_1991 & & $\begin{array}{c}0.377 \\
(23.13)^{* * *}\end{array}$ & $\begin{array}{c}0.436 \\
(25.74)^{* * *}\end{array}$ & $\begin{array}{c}0.443 \\
(17.97)^{* * *}\end{array}$ \\
\hline D_contiguity & & & $\begin{array}{c}1.757 \\
(5.97)^{* * *}\end{array}$ & $\begin{array}{c}1.964 \\
(6.23)^{* * *}\end{array}$ \\
\hline D_common_language & & & $\begin{array}{c}1.079 \\
(17.05)^{* * *}\end{array}$ & $\begin{array}{c}0.917 \\
(11.34)^{* * *}\end{array}$ \\
\hline D_colonial_relationship & & & $\begin{array}{c}0.470 \\
(6.32)^{* * *}\end{array}$ & $\begin{array}{c}0.353 \\
(3.53)^{* * *}\end{array}$ \\
\hline weighted distance & & & $\begin{array}{c}-0.850 \\
(10.39)^{* * *}\end{array}$ & $\begin{array}{l}-0.927 \\
(17.97)^{* * *}\end{array}$ \\
\hline Observations & 4945 & 4935 & 4935 & 4935 \\
\hline Number of id_push & 766 & 766 & 766 & 766 \\
\hline R-squared within & 0.223 & 0.320 & 0.410 & \\
\hline rho & & & & $0.27^{* * *}$ \\
\hline
\end{tabular}

Absolute value of $\mathrm{t}$ statistics in parentheses

$\mathrm{SE}$ and statistics are robust to both arbitrary and intra-group heteroskedasticity

${ }^{*}$ significant at $10 \%$; ${ }^{* *}$ significant at $5 \%$; ${ }^{* *}$ significant at $1 \%$

affect positively bilateral migration flows, while distance negatively affects migration flows. This result is coherent with both Mayda (2008), Ortega and Peri (2009) and Berthelemy, Beuran and Maurel (2009). The fitted values of regression (2) are the estimated bilateral flows of immigrants from origin countries to destination countries. Notice that the set of destination countries has been removed from the set of origin countries. ${ }^{29}$

Table 4 shows the results for estimated equation (3). ${ }^{30}$ As we expected both the expenditure in tertiary level education and the number of patents in destination

29 This choice has been forced by the fact that bilateral flows of aid in OECD database did not include destination countries as receiving aid countries.

30 Notice that although we have 24 destination countries, 86 origin countries and 10 years, we estimated equation (4) using just 8447 observations because of a huge number of missing values for bilateral flows of immigrants in OECD dataset. 
Table 4: Results for Bilateral Skilled Focused Migration Flows Estimation: 1998-2007 in 24 OECD Countries from 86 Poor and Developing Countries

Dependent variable Bilateral skilled immigrants flows in $\ln$

(1)

(2)

(3)

\begin{tabular}{lccc}
\hline Expenditure in tertiary edu (ln) & 0.606 & 0.275 & -0.034 \\
No. of patent (ln) & $(25.91)^{* * *}$ & $(17.24)^{* * *}$ & $(1.19)$ \\
& 0.085 & 0.038 & 0.224 \\
ln_skilled_immi_1991 & $(4.72)^{* * *}$ & $(3.31)^{* * *}$ & $(9.19)^{* * *}$ \\
D_contiguity & 0.430 & 0.523 \\
& & $(46.51)^{* * *}$ & $(35.72)^{* * *}$ \\
D_common_language & 0.098 & 0.012 \\
& & $(1.70)^{*}$ & $(0.15)$ \\
D_colonial_relationship & 0.867 & 0.53 \\
& & $(20.40)^{* * *}$ & $(9.76)^{* * *}$ \\
weighted distance & -0.063 & 0.096 \\
& & $(1.25)$ & $(1.58)$ \\
\hline Observations & -0.697 & -0.34 \\
Number of id_push & $(19.07)^{* * *}$ & $(9.40)^{* * *}$ \\
\hline R-squared within & & 8402 & 8402 \\
rho & 1099 & 1099 & 1099 \\
\hline
\end{tabular}

Absolute value of $\mathrm{t}$ statistics in parentheses

SE and statistics are robust to both arbitrary and intra-group heteroskedasticity

${ }^{*}$ significant at $10 \%{ }^{* *}$ significant at $5 \%$; ${ }^{* *}$ significant at $1 \%$

countries attract the inflows of tertiary educated immigrants (coefficients positive and significant). Coefficients associated to geographic variables have the same signs as in estimation (2) (except for colonial relationship which now is not significant). Origin countries are mainly poor or developing countries, so on the average with a worse educational system than in rich countries. For this reason, the estimated values of bilateral flows keep those migrants with a lower quality of education than natives even if formally they are tertiary educated as well. Since the bilateral immigration flows may be left censored at zero, as a robustness check we also estimated equations (2) and (3) by using a panel tobit model. The underlying idea is that the flow of immigrants is broadly a continuous variable but it is subject to a lower limit. ${ }^{31}$ The result of the tobit estimation is shown in 
the last column in Tables 3 and 4, the values of the coefficients are mainly the same as those for the within estimations, the correlation indexes between the fitted values using within (OLS) and tobit estimators are close to one. Moreover the agglomeration of zeros in the data set is negligible, so the bias due to a simple OLS estimation is negligible too. Because the agglomeration of zeros in the data set is negligible and the fitted values resulting from the OLS estimation are more similar to the actual values in term of magnitude, we use the fitted values of the OLS model as instrumental variable in our 2SLS estimation. ${ }^{32}$

\subsubsection{The Quality of the Instruments}

An instrumental variable must satisfy two requirements: it must be correlated with the endogenous variables (relevance) and orthogonal to the error process (validity). The former condition may be tested by looking at the fit of the first stage regressions; usually one should look at the $\mathrm{R}^{2}$ or at the F-stat of joint significance of the instruments in the first stage regression. Unfortunately, these indicators may not be sufficiently informative because we have two endogenous regressors. Indeed it may be the case that only one of the two instruments is highly correlated with the two endogenous regressors and the other is just noise, giving however high first stage $\mathrm{R}^{2}$ or F-stat in the first stage regressions, but the model is basically unidentified.

In order to show the relevance of the so built instrumental variables, in Figure 4 we report the scatter plots of the actual values for immigrants' inflows, both total and skilled one, against the fitted values of respectively estimated equations (2) and (3). The correlation between actual values and fitted values is positive and quite significant, so our instruments are good proxies for actual values of immigrants' inflows. To strengthen this evidence we also regress actual values of migration against the fitted values from equations (2) and (3) and a constant term, results are shown in Table 5. As expected the coefficient of the fitted values of total immigrants flows is significant and close to one in explaining the actual values of total migration flows; similarly the estimated values of skilled migration flows has a significant coefficient close to one in explaining the flows of skilled migrants. Finally we also look at the Kleibergen-Paap F statistic as a weak identification test (results are in Table 6) and we can reject the null of weakly identified first stage equation.

31 See also Beine, Docquier and Ozden (2009) and Felbermayr, Hiller and Sala (2008).

32 Results of the 2SLS procedure using the estimated bilateral immigrants flows using tobit estimation are equal to those by using OLS. 
Figure 4: Relation between the True Immigrants Inflows and the Estimated Inflows of Immigrants as in Model [2] and [3] in 1998 (a, b) and 2007 (c, d)

(a)

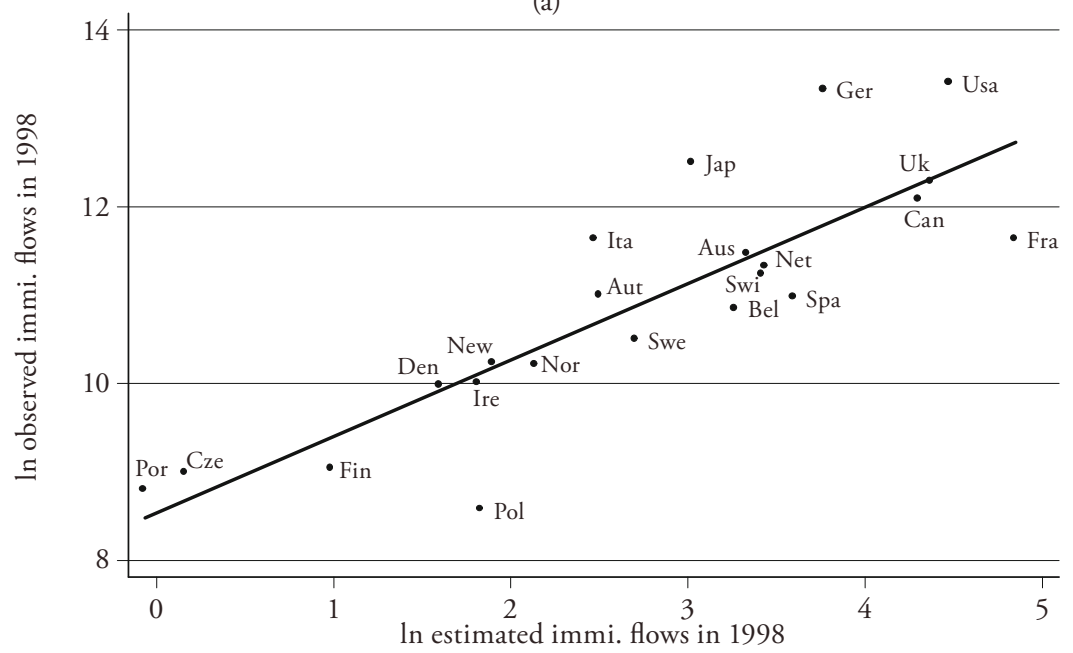

(c)

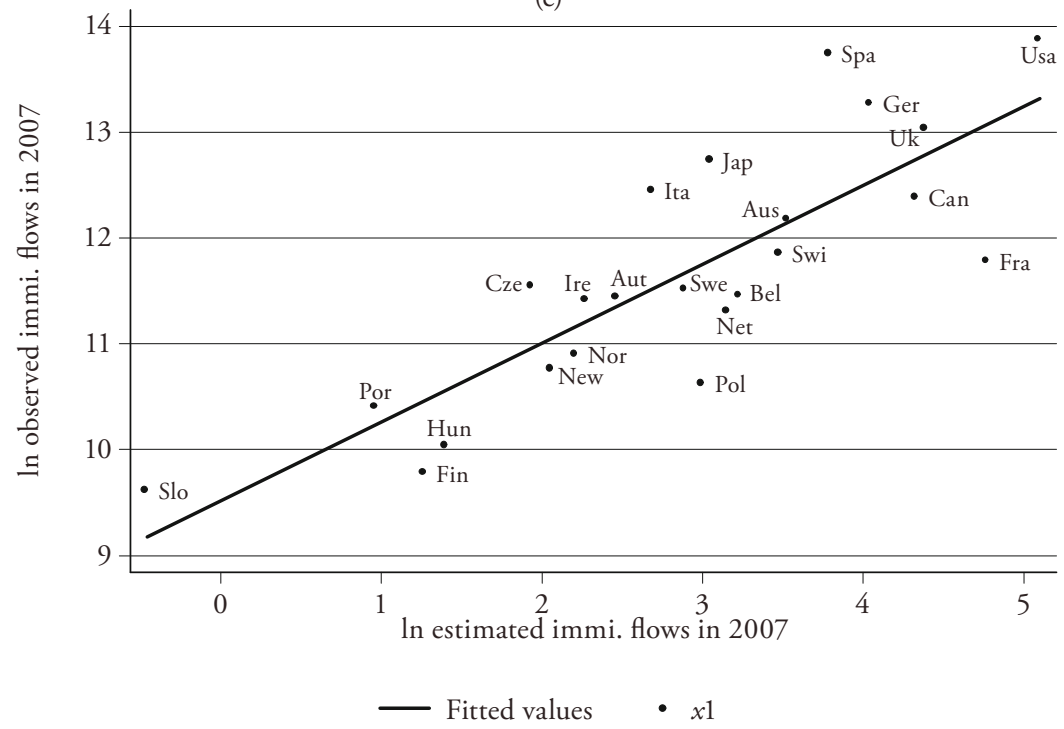

Source: F. Docquier, A. Marfouk and B.L.Lowell; and OECD.stat. 
Figure 4 continued

(b)

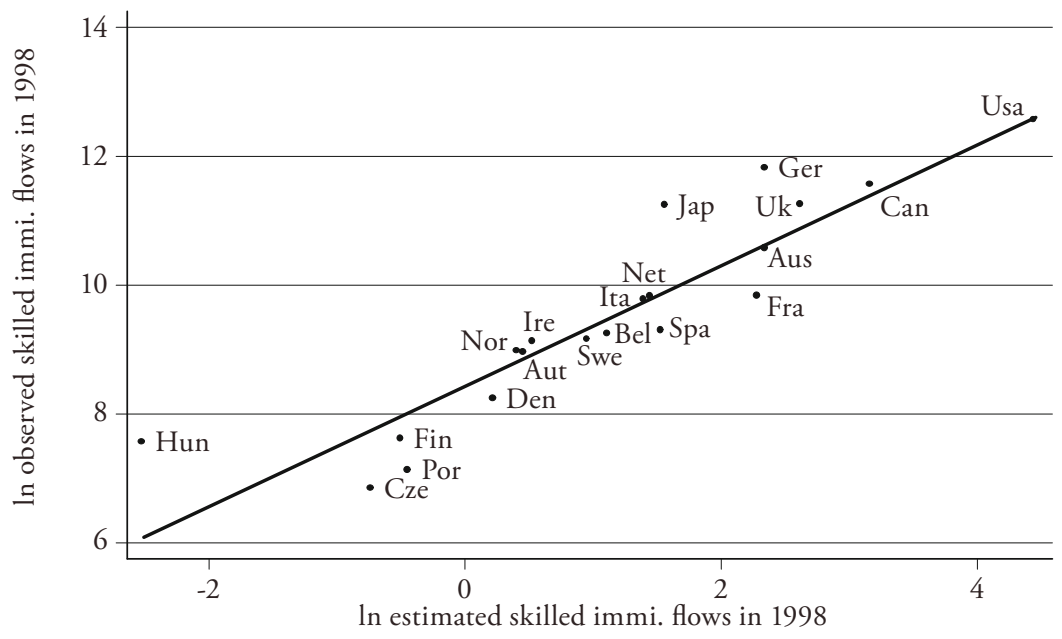

(d)

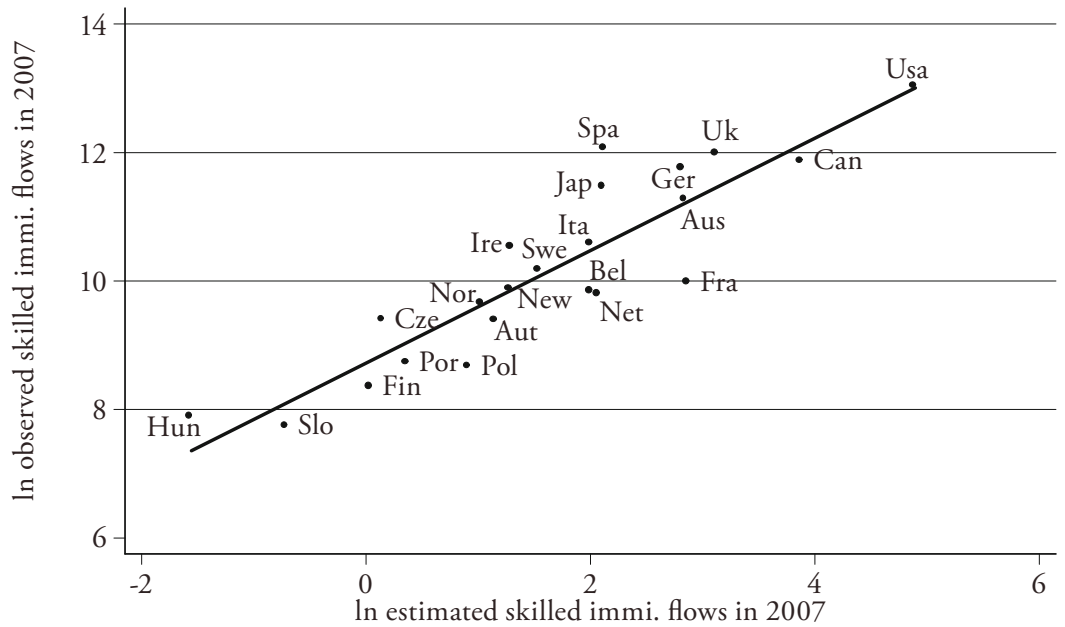

- Fitted values $\quad$ - $x 2$

Source: F. Docquier, A. Marfouk and B.L.Lowell; and OECD.stat. 
Table 5: Relation between the Actual and Estimated Flows of both Immigrants and Tertiary Educated Immigrants

\begin{tabular}{lcc}
\hline Dependent variable & In_immi & In_skilled_immi \\
\hline constant & 8.122 & 8.231 \\
& $(26.74)^{* * *}$ & $(54.71)^{* * *}$ \\
In_estimated_immi & 1.145 & - \\
In_estimated_skilled_immi & $(10.52)^{* * *}$ & \\
& - & 1.168 \\
\hline Fixed Effects & & $(10.48)^{* * *}$ \\
\hline R-sq & Yes & Yes \\
F-stat & 0.35 & 0.36 \\
Observations & 110.73 & 109.89 \\
Number of nuts & 229 & 219 \\
\hline
\end{tabular}

Absolute value of $\mathrm{z}$ statistics in parentheses

${ }^{*}$ significant at $10 \%$; ${ }^{* *}$ significant at $5 \%$; ${ }^{* * *}$ significant at $1 \%$

Unfortunately we cannot directly test the validity of the instrumental variables (Sargan or Hansen test) because the Hansen J test for overidentifying restriction is not valid in the just identified model (Cameron and Trivedi, 2009). So firstly we rely on the former discussion about the exogeneity of the determinants of bilateral migration flows but for the estimation (1) where the endogeneity problem is crucial we also provide a formal overidentifying test by adding three surely orthogonal (even if irrelevant) ${ }^{33}$ instruments and test a subset of overidentifying restriction (Baum, Schaffer and Stillman, 2003). The idea is to transform the model into an overidentified model, in order to have a group of orthogonal instruments and a group of suspect non-orthogonal instruments (i.e. our actual instruments described in the former section); thus we estimate a restricted model ${ }^{34}$ with only surely orthogonal instruments and an unrestricted model with all the instruments (containing the suspect instruments). If the inclusion of suspect

33 We don't care about relevance of the added instruments because they are used only to test the exogeneity of our two actual instruments.

34 Since the restricted model has to be identified as well, the number of added and surely orthogonal instruments has to be at least equal to the number of problematic variables. 


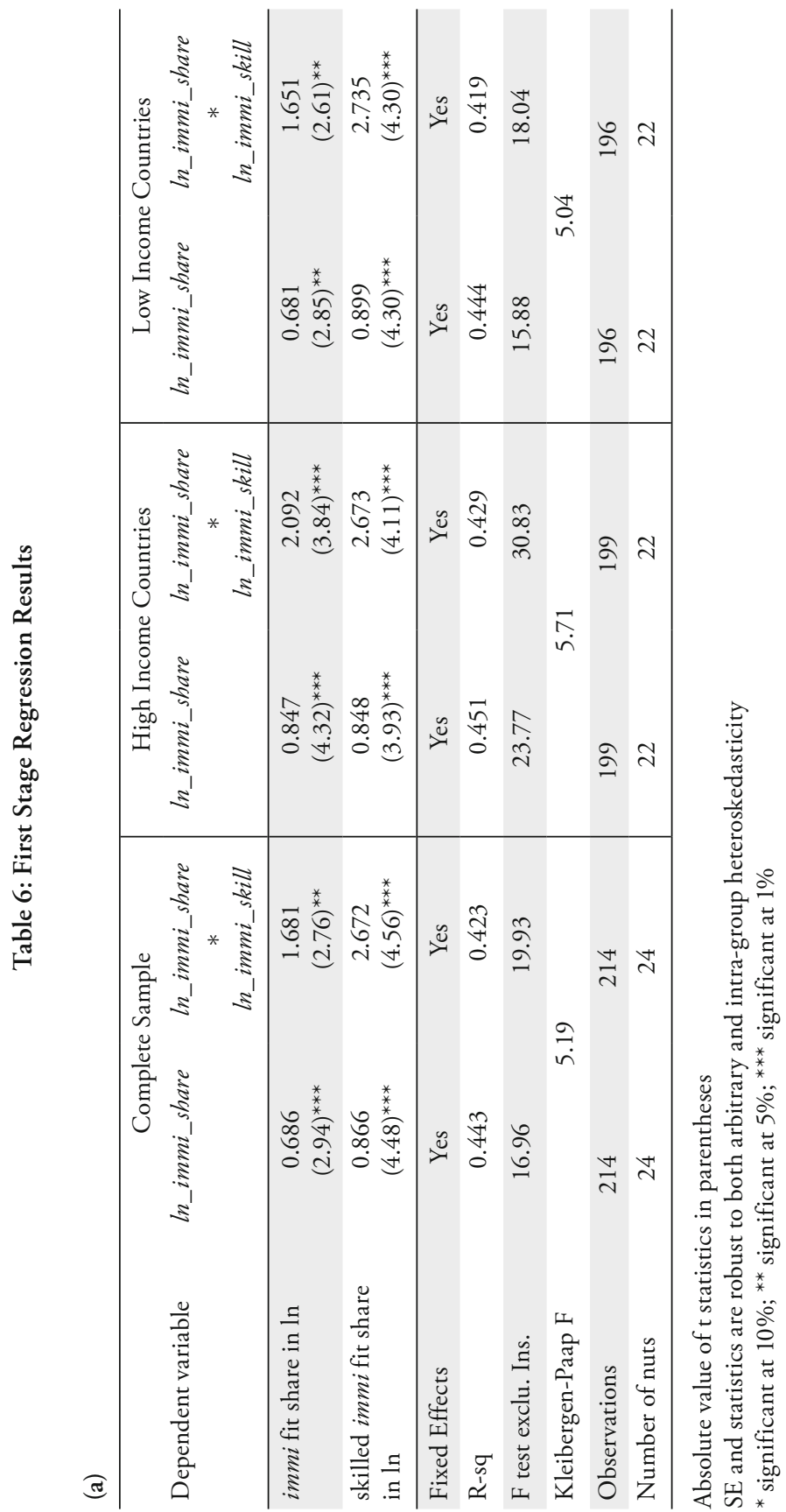




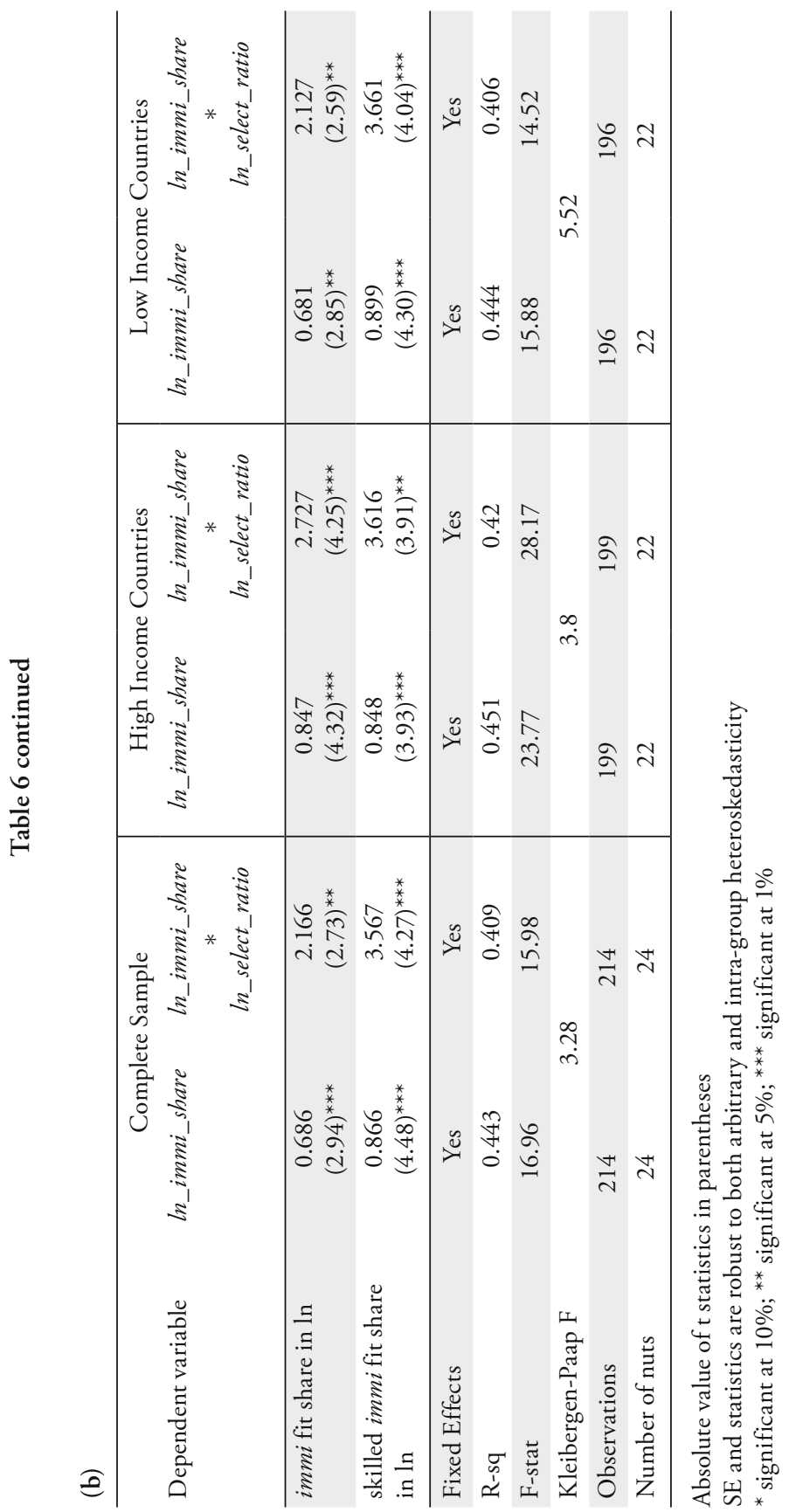


instruments increases significantly the Hansen J statistics, we would have good reasons for doubting the orthogonality of our suspect instruments. ${ }^{35}$ We could not reject the null of exogeneity of suspect instruments, so we may conclude that the estimated flows of total and skilled migrants (from equation (2) and (3)) are valid instruments for the estimation of equation (1).

\subsection{Estimates of Immigration's Effects on Income Variation}

\subsubsection{Specification}

Having our two instrumental variables, we are allowed to estimate the effect of immigrants and their skill level on per capita GDP by using equation (1). In panel data context, it is often assumed that observations on the same individual (cluster) in two different time periods are correlated (Baum, Schaffer and Stillman, 2003), but observations on two different individuals are not; so in estimating equation (1) we properly accounted for cluster robust standard errors. By estimating equation (1) using a fixed effects model, $\beta_{1}$ is the elasticity of a variation of unskilled immigrants inflows about its mean (conditional to having zero tertiary educated share of immigrants) on per capita GDP variation about its time mean; while $\beta_{2}$ gives us the effect of being tertiary educated among immigrants on per capita GDP variation. Thus, from what we know about the related theoretical literature, we expect $\beta_{1}<0$ and $\beta_{2}>0$. So potentially the effect of a selective immigration policy (aimed to increase the share of tertiary educated over total immigrants) on per capita GDP can be evaluated by looking at $\beta_{2}$. As a proxy for the human capital content of immigrants has been used the share between tertiary educated immigrants stock over the total immigrants in each destination country, this measure points to evaluate the effects of an increase in the human capital content by immigrants (due for example to a selective immigration policy). Notice that the role of the level of tertiary educated home born workers is kept by the fixed effect (the idea is that the lower is the endowment of native high skilled workers, the higher is the positive effects of high skilled immigrants). As stated in the former section, an OLS model introduces a bias in our estimation, so we need an IV panel model (2SLS). ${ }^{36}$ So in the first stage regressions we need

35 Practically, we added three surely orthogonal instruments with respect per capita GDP, from the OECD stat we choose the number of deaths for suicide and for diabetes per 100,000 inhabitants and the alcohol consumption per capita.

36 Notice that part of the endogeneity problem due to the omitted variables problem is cleared out by the country's fixed effects. 
at least two instrumental variables to correctly identify the model. Our instruments are two estimated immigrants inflows in (2) and (3), aggregated for each destination country and weighted for the population in each country. The destination country's fixed effect in (1) explains all those factors that are country specific and may influence per capita GDP; they reflect for instance differences in the initial level of efficiency or technology between countries.

\subsubsection{Basic Results}

Table 7 reports the estimation of equation (1) by using simple OLS model (fixed effects panel model) and IV panel model. The coefficients associated to the share of immigrants inflows are negative and significant for both OLS and IV estimation. The coefficients associated to the interacted variable are positive and very significant. The results for the Durbin-Wu-Hausman test in Table 7 confirm the bias in the OLS estimation due to the endogeneity problem. ${ }^{37}$ So we have to look at the IV estimation results, and we may conclude that a $1 \%$ increase in zero human capital endowed immigrants inflows variation leads to a $1.1 \%$ reduction in per capita GDP variation, but being skilled among immigrants mitigates this negative effect. Since the coefficient associated to the immigrants share is always greater than the coefficient associated to the interacted variable (skill content of immigration), we may conclude that being tertiary educated among immigrants positively affects per capita GDP but not enough to clear the negative effect of immigration. ${ }^{38}$ With respect the paper by MARIYA and TRITAH (2009), which has the merit to accounting for immigrants' heterogeneity in determining the effect on per capita GDP, here we find strong and significant positive effect of being skilled among immigrants on host countries' economic performances.

Table 6 reports the first stage regressions results, our instrumental variables explain well our problematic variables: all coefficients are statistically positive and different from zero, the $\mathrm{R}^{2}$ of the first stages are quite good and the F-stat tests for zero slopes seem to confirm the jointly significance of instrumental variables. But, unfortunately in presence of two endogenous variables (as in this case) the

37 The Durbin-Wu-Hanson test investigates if the correlation between the actual flows of immigrants are uncorrelated with the error component (exogeneity). Under the hypothesis that actual immigrants flows are uncorrelated with the error term, the OLS estimation are unbiased (as IV estimation) and efficient; so OLS and IV coefficients differs only because of sampling error. Since we can reject the null hypothesis, we conclude that OLS coefficients differ from IV, so OLS estimation are biased because of endogeneity of actual immigrants flows.

38 Even by assuming a share of tertiary educated immigrants equal to one, the overall effect on per capita GDP variation is still negative. 


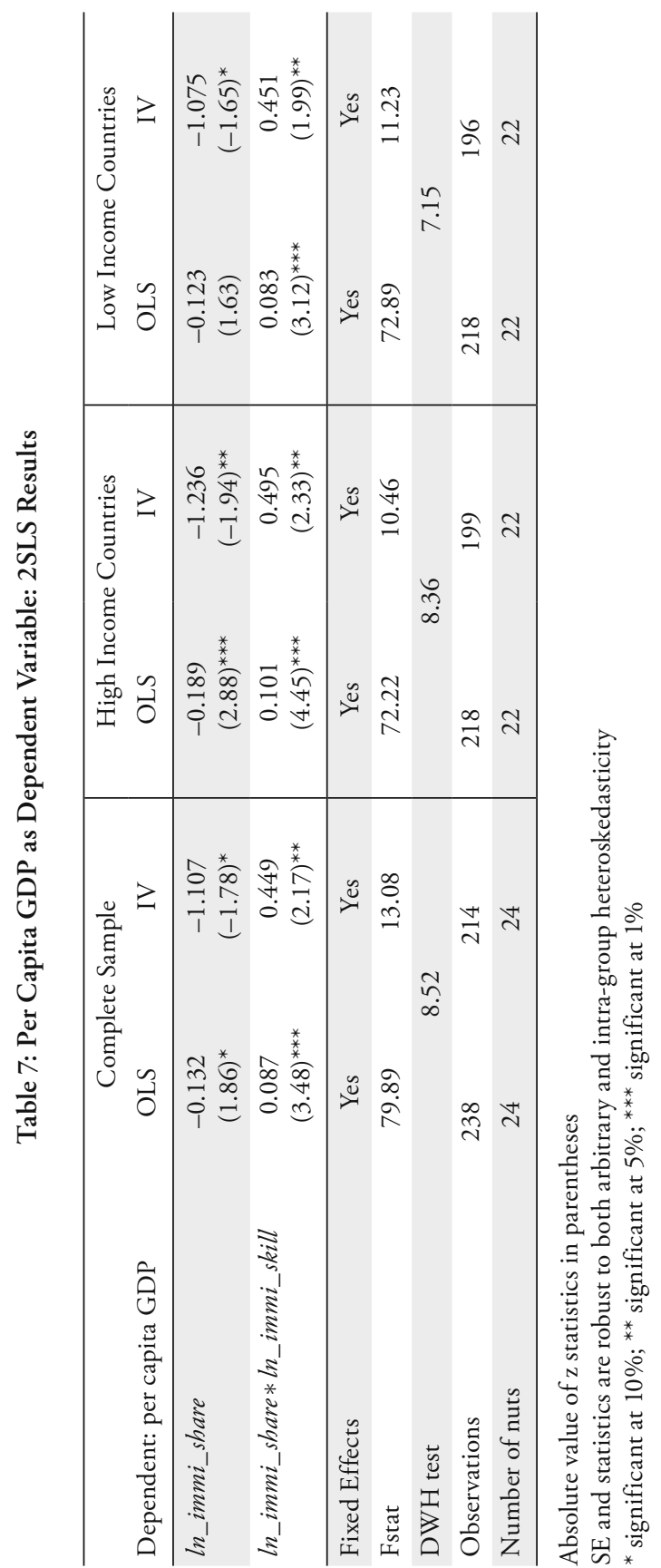


usual rules of thumbs may be misleading, so we computed the weak identification test (adjusted for the robust cluster heterogeneity) by using the KleibergenPaap F statistic, confirming that there are not problem on weak instruments.

The high negative effect of average immigrants on per capita GDP may have two possible explanations. A possible explanation relies on the fact that per capita GDP measure suffers of an increase in the number of inactive immigrants. This is a well known feature in migration literature: family reunion involves inactive foreign born individuals (such as children). A second possible explanation is the assimilation problem. When a migrant arrives in his destination country, he takes time before finding a job, so it strongly negatively affects per capita GDP. To solve for the inactive immigrants problem we replicate the same estimation as before by using per hour worked GDP (this measure does not suffer the inflow of inactive population and it has been often taken as a proxy for the country's macroeconomic labor productivity measure). ${ }^{39}$

Table 8 shows results when the dependent variable is per hour worked GDP (still in difference from its own time mean), it is interesting to notice that the coefficients associated to immigration share are all lower than those in Table 7 and not statistically different from zero, this confirms our intuition that per capita GDP suffers of inactive immigrants (this results is in line with the widely accepted idea in literature that immigrants have a small negative effect on wages in host countries). But the actual end of this paper is to understand if there is place for skill selective immigration policy, and the positive and significant coefficient for the interacted variable confirms that being skilled among immigrants has a positive effect on the host country's per hour worked GDP variation. Observing that per hour worked GDP can be considered as a measure for macroeconomic labor productivity, we may conclude that the inflows of tertiary educated immigrants have a positive effect on labor productivity variation. Moreover, since $\beta_{1}$ is not statistically different from zero, we may say that the overall effect of immigration on labor productivity variation is positive, confirming results in SPARber (2010) (this is not true in the limit case of zero human capital endowed immigrants).

\subsubsection{Robustness}

As a robustness check we replicated the same estimation in (1) for two other subsamples of data: (i) high income countries obtained by excluding the two poorest countries in the original sample (Poland and Slovak Republic); (ii) low income 


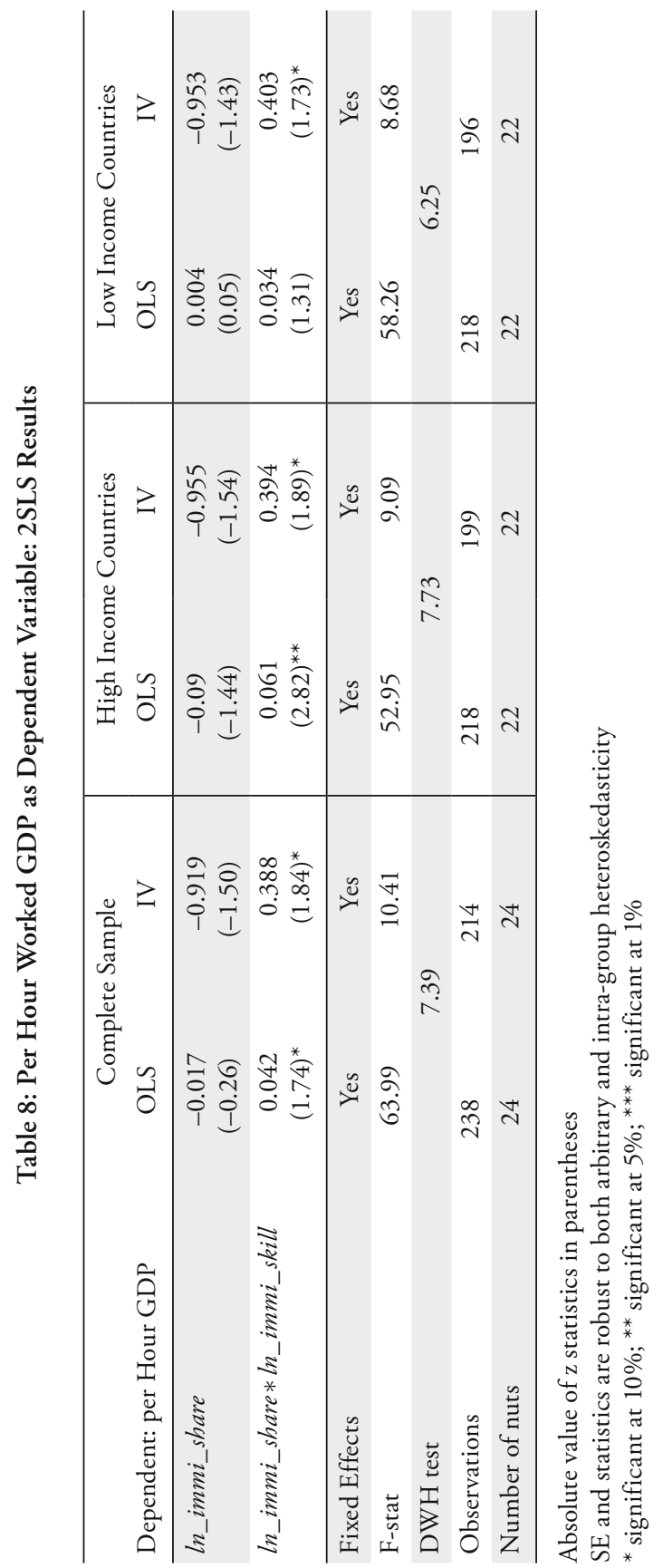


countries obtained by excluding United States and Canada. Results in Tables 6-8. For these two others samples used, the effect of average immigration on per capita GDP variation is still negative and significant, and the effect of the interacted variable (in other words the effects of being tertiary educated among immigrants) is again positive and significant for both OLS and IV estimations. It is interesting to notice that the negative effect of average immigrants on per capita GDP variation for the high income countries sample is higher that for low income countries sample (while coefficient on the interacted variable remains roughly unchanged), this may be due to the fact that the inactive migrants problem in high income countries is stronger than in low income countries. ${ }^{40}$

As a further robustness check we replicate the same analysis by using the selection ratio to interact the immigrants flows. The selection ratio is the number of skilled over unskilled migrants, in our case it has been computed as the ratio between the stocks in 2000 of tertiary educated immigrants over primary educated immigrants. This variable is a proxy for the human capital structure of migration stock, but by interacting it with the flows of immigrants, we have a proxy for the human capital structure of the immigrants flows. For all the three samples used for the estimation, we obtain similar coefficient to the case in which the share of skilled immigrants was used to interact the immigrants flows. Table 9 shows that an increase in the human capital structure of immigrants flows toward tertiary educated immigrants (e.g. an increase in the number of skilled versus the number of unskilled immigrants) would have a positive effect on per capita GDP (and on per hour worked GDP) variation, but again, the negative effect of average immigrants inflows ${ }^{41}$ overcompensates this positive effect. The same results are obtained by using the two subsamples defined before (high and low income countries). This confirms the theoretical results in Benнabib (1996) that the impact of immigration strongly depends on the human capital structure of immigrants flows. Finally, this also gives a role to a skill selective immigration policy (aimed to increase the selection ratio) in affecting positively income in host countries.

40 A more rigorous test for this hypothesis should be conducted by using variable concerning countries' regulation on family reunion policy.

41 First stage regressions results for this new estimations are reported in Table 6 (b). 


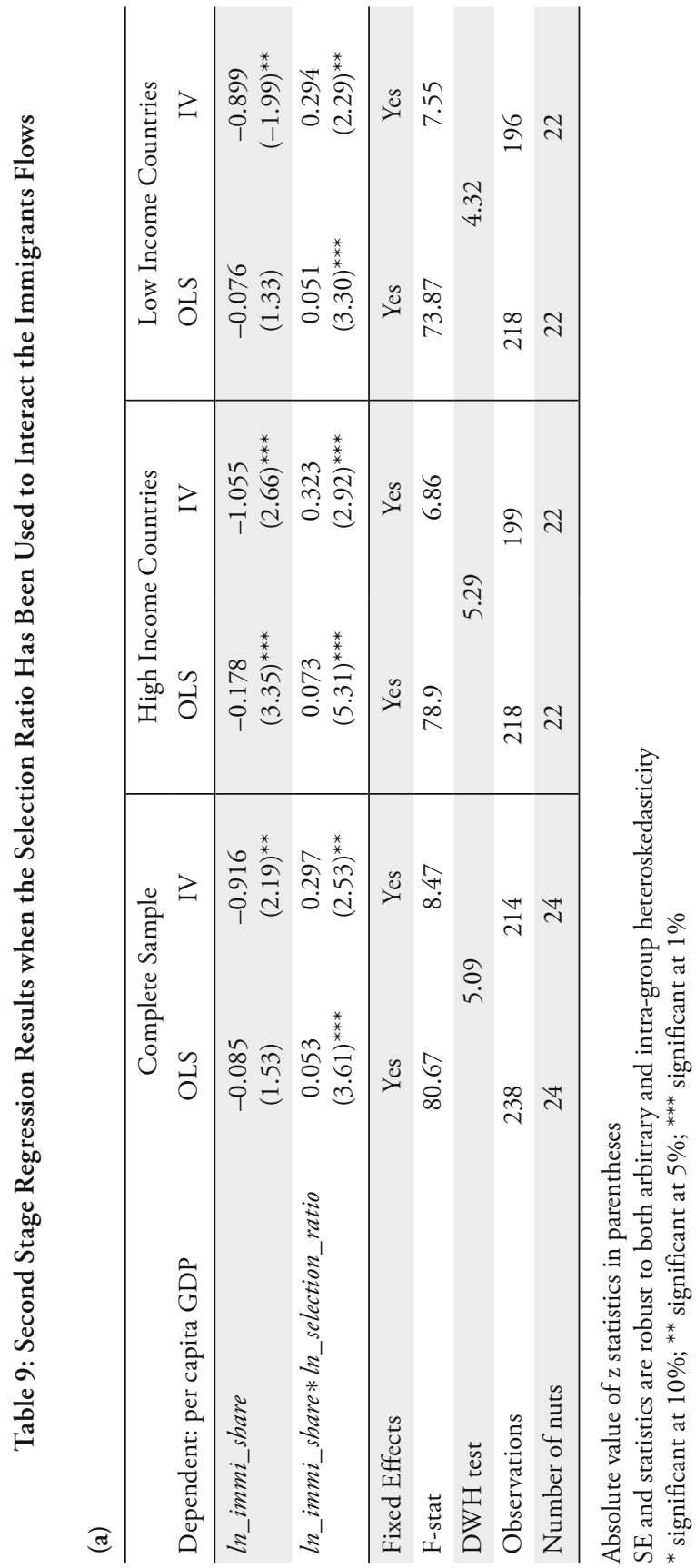




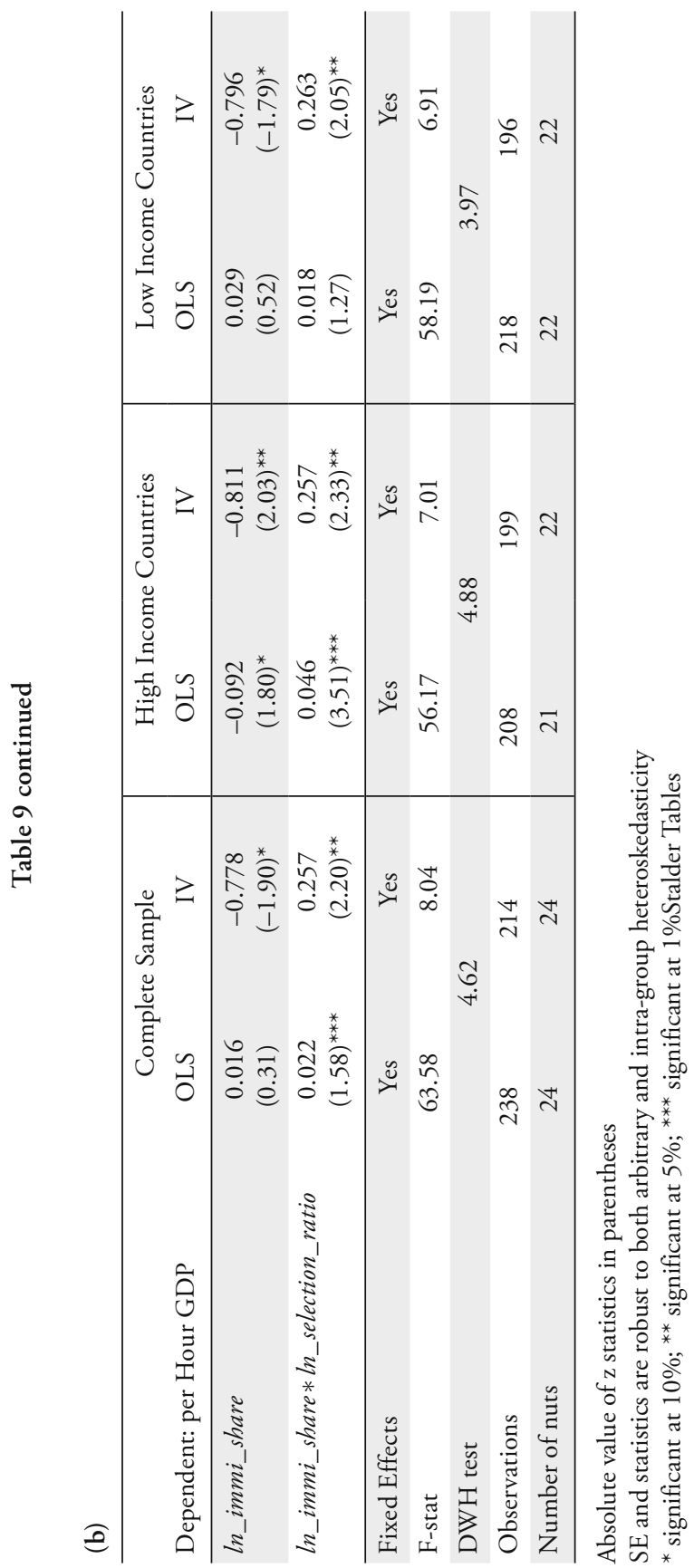




\subsubsection{Why Are the IV Estimates Greater than the OLS Estimates?}

As one may easily notice from Tables 7, 8 and 9 coefficients estimated using IV are greater than those estimated using OLS. This is a good point for our results, and let's see why. The OLS estimates are given by the correlation between income and migration, while IV estimates are given by the correlation between income and the component of migration explained by our instruments. Thus, the fact that OLS estimates are smaller than IV ones, means that the correlation between income and the component of migration does not explained by our instrument (in other words the error term of the first stage regression) is weaker than its correlation with the component of migration explained by the instruments.

\section{Conclusions}

The aim of the paper was to investigate the effect of immigrants flow and its human capital content on host country's income variation ${ }^{42}$. Negative effect of immigrants arises under a neoclassical production function where immigrants are considered as an increase in low productive workers. But allowing for the possibility that migrants can bring along them some human capital from their origin country, the human capital dilution given by the increased population may be offset. Under this setting the effect of immigration on host countries income depends on the human capital content of immigrants. So in the paper we estimated the effects of immigrants and their skill level on host countries income variation. We provide evidence of the positive effect of being skilled among immigrants on per capita GDP variation about its mean by using instrumental variable panel data model (fixed effects for destination countries), but the overall effect of immigrants' inflows is still negative. In particular a $1 \%$ increase in the variation of zero human capital endowed immigrants inflows leads to a $1.1 \%$ decrease in per capita GDP deviation from its time mean, while being high skilled among immigrants contributes $0.45 \%$ positively on per capita GDP variation. Similarly, a $1 \%$ increase in the selection ratio of immigrants flows variation leads to a $0.29 \%$ increase in per capita GDP variation (but again it not enough to clear the negative effect of the overall immigrants inflows). So we may certainly conclude in favour of a skill selective immigration policy aimed to increase the share of skilled

42 In doing this, we pointed to stress the relevance and the validity of our instrumental variables because it is a crucial point in all the literature concerning immigration as independent variable. 
over unskilled immigrants. There are some possible reasons of why immigrants have a so negative effect on per capita GDP. Among them we decided to explore the problem of inactive immigrants that reduce itself per capita GDP measure. We solved this problem by using per hour worked GDP as dependent variable. By using the latter as a dependent variable we obtain some interesting results: (i) unskilled immigrants have a null effect on per hour worked GDP variation (that can be alternatively interpreted as a macroeconomic labor productivity measure); while (ii) being skilled among immigrants has a positive effect on per hour worked GDP variation. So we may conclude that in the limit case that immigrants have zero human capital content, their effect on labor productivity variation is null; but allowing for some human capital content of immigrants (which is the most realistic case) their effect is positive on labor productivity variation.

Some other possible theoretical reasons for the so negative effect of immigrants on income variation is that the human capital content of immigrants (from poor countries, as in our estimation) is even lower than the human capital content of native workers in OECD countries (this is the idea by Dolado, Goria and ICHINO, 1994). An other explanation is that physical capital does not immediately adjust after immigrants inflows (this is the explanation given in literature for the negative effect of immigration on national wages); so a further step in this strand of literature would be to consider inflows of foreign capitals as a possible help in the adjustment of physical capital after immigration inflows. Intermediate results of the paper are: (i) having found further evidence of the importance of geographic variables and bilateral aid as determinants of bilateral migration flows, (ii) having tested our instrumental variables for their relevance and validity, allowing them to be used in many other estimations involving immigration as independent variable.

\section{References}

Aydemir, Abdurrahman, and George J. Borjas (2007), "A Comparative Analysis of the Labor Market Impact of International Migration: Canada, Mexico and the United States", Journal of the European Economic Association, 5, pp. 663-708.

Altonji, Joseph, and David Card (2001), "The Effects of Immigration on the Labor Market Outcomes of Less-Skilled Natives", in: Abowd J. and R. Freeman (ed.), Immigration Trade and The Labor Market, Chicago, University of Chicago Press. 
Barro, Robert, and Xavier Sala-I-Martin (1992), "Regional Growth and Migration: A Japan-United States Comparison", Journal of the International and Japanese Economies, 6, pp.312-346.

Baum, Christopher, Mark E. Schaffer and Steven Stillman (2003),

"Instrumental Variables and GMM: Estimation and Testing", Stata Journal, 3, pp. 1-31.

Beine, Michel, Frederic Docquier and Caglar Ozden (2009), "Diasporas",

Discussion paper, CESifo Working Paper no. 2607.

Bellini, Elena, Gianmarco I. P. Ottaviano, Dino Pinelli and Giovanni

Prarolo (2009), "Cultural Diversity and Economic Performance: Evidence from European Regions", Working Paper, Fondazione Enrico Mattei.

Benhabib, Jess (1996), "On the Political Economy of Immigration”, European Economic Review, 40, pp. 1737-1743.

Berthelemy, Jean-Claude, Monica Beuran and Mathilde Maurel (2009), "Aid and Migration: Substitutes or Complements?", World Development, forthcoming.

Borensztein, Eduardo, Jose de Gregorio and Jong-Wha. Lee (1998), "How

Does Foreign Direct Investment Affect Economic Growth?", Journal of International Economics, 45, pp. 115-135.

Borjas, George (1995), “The Economic Benefits from Immigration”, Journal of Economics Perspectives, vol. 9, n. 2.

Borjas, George (2003), "The Labor Demand Curve is Downward Sloping: Re-examining the Impact of Immigration on the Labor Market", Quarterly Journal of Economics, 118, pp. 1335-1374.

Borjas, George (2006), "The Impact of Immigration on the Labor Market", paper prepared for the IMF conference in Labor and Capital in Europe following enlargement.

Borjas, George, and Lawrence Katz (2007), "The Evolution of the Mexican-Born Workforce in the United States", in: George Borjas (ed.), Mexican Immigration to the United States, NBER conference report.

Borjas, George, Jeffrey Groggger and Gordon H. Hanson (2008), "Imperfect Substitution between Immigrants and Native: a Reappraisal”, NBER working paper n. 13887.

Cameron, Colin, and Pravin K. Trivedi (2009), Microeconometrics Using Stata, ed. Stata Press Publication.

Card, David (2001), "Immigrants Inflows, Native Outflows, and the Local Labor Market Impacts of Higher Immigration”, Journal of Labor Economics, 19, pp. 22-64. 
Card, David (2005), “Is the New Immigration Really So Bad?”, The Economic Journal, 115.

Chaloff, Jonathan, and George Lemaitre (2009), "Managing Highly Skilled Labour Migration: A Comparative Analysis of Migration Policies and Challenges in OECD Countries", Working Paper, OECD.

Cortes, Patricia (2008), "The Effects of Low Skilled Immigration on US Prices: Evidence from CPI Data”, Journal of Political Economy, 116 (3).

De Mello, Luiz R. (1999), "Foreign Direct Investment-Led Growth: Evidence from Time Series and Panel Data”, Oxford Economic Paper, 51, pp. 133-151.

Docquier, Frederic, Lindsay B. Lowell and Abdeslam Marfouk (2007), "A Gendered Assessment of the Brain Drain", IZA discussion paper n. 3235.

Dolado, Juan, Alessandra Goria and Andrea Ichino (1994), "Immigration, Human Capital and Growth in the Host Country, Evidence from Pooled Country Data", Journal of Population Economics, 7, pp. 193-215.

Felbermayr, Gabriel, Sanne Hiller and David E. Sala (2010), "Does Immigration Boost per Capita Income?”, Economics Letters, 107 (2), pages pp. 177-179.

Friedberg, Rachel M., and Jennifer Hunt (1995), "The Impact of Immigrants on Host Country Wages, Employment and Growth", Journal of Economics Perspectives, 9 (2).

Friedberg, Rachel M. (2000), "You Can't Take It with You? Immigrant Assimilation and the Portability of Human Capital", Journal of Labor Economics, $18(2)$.

Frankel, Jeffrey A., and David Romer (1999), “Does Trade Cause Growth?”, The American Economic Review, 89 (3), pp. 379-399.

Hanson, Gordon H. (2008), "The Economic Consequence of International Migration of Labor", NBER working paper no. 14490.

Kemnitz, Alexander (2001), "Endogenous Growth and the Gains from Immigration”, Economics Letters, 72, pp. 215-218.

Mankiw, Gregory, David Romer and David Weil (1992), "A Contribution to the Empirics of Economic Growth", Quarterly Journal of Economics, vol. 107, pp. 407-437.

Mayda, Anna Maria (2008), "International Migration: A Panel Data Analysis of the Determinants of Bilateral Flows", Journal of Population Economics, forthcoming.

Mariya, Aleksynska, and Ahmed Tritah (2009), "Immigration, Income and Productivity of Host Countries: A Channel Accounting Approach", CEPII document de travail. 
Michaely, Michael (1977), "Exports and Growth: An Empirical Investigation.", Journal of Development Economics, 4(1), pp. 49-53.

Ortega, Francisco, and Giovanni Peri (2009), "The Causes and Effects of International Migration: Evidence from OECD Countries 1980-2005”, NBER working paper 14833.

Ottaviano, Gianmarco I., and Giovanni Peri (2008), "Immigration and National Wages: Clarifying the Theory and Empirics", CEPR discussion paper 6916.

Zhang, Kevin H. (2001), "Does Foreign Direct Investment Promote Economic Growth? Evidence from East Asia and Latin America”, Contemporary Economic Policy, 19, pp. 175-185.

Sparber, Chad (2010), "Racial Diversity and Macroeconomic Productivity across US States and Cities”, Regional Studies, 44 (1).

\section{SUMMARY}

This paper investigates the effects of immigration flows and their human capital content on per capita GDP variation in 24 OECD host countries. Theoretical models concludes that the effect of immigrants in host country's income depends on the human capital content of migrants (BеNнавів, 1996); empirically the question is still open and this paper contributes to make light on this. So we propose an empirical estimation on the effects of immigrants and their human capital content on per capita GDP variation. Using a IV model to solve the endogeneity problem we found that high human capital content by immigrants has a positive effect on per capita GDP variation, but it is not enough to fully compensate the overall negative effects of migration on changes in per capita output. 